ARTICLES 


\title{
Framing a Young Nun's Initiation: Early Modern Convent Entry Sermons in the Habsburg Lands. Vestiges of a Lost Oral Culture
}

\author{
VERONIKA ČAPSKÁ
}

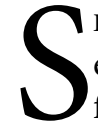

ERMONS REPRESENT THE MAIN TYPE OF SOURCES related to convent entry ceremonies in early modern Central Europe. Other textual sources seem to be quite rare (e.g., songs) or formulaic (e.g., written professions). Visual and material sources (portraits, strands of hair) are also scarce. Yet the significance of entry or monachization sermons in this respect has hardly been recognized. ${ }^{2}$ The aim of this article is to contribute to their due scholarly appreciation by demonstrating the interpretative possibilities that their research can offer. I will attempt to do so by exploring these sermons from a wide range of approaches-above all from the perspectives of media and communication studies, gender studies, cultural and social anthropology, and literary and visual studies. This complexity of approaches will enable me to answer a series of questions: Why were the monachization sermons widely popular? What were their functions and uses? What parallels can be drawn between monachization sermons and other sources? Finally, how can their research contribute to a greater understanding of early modern convent culture?

The term "framing" in the title of my article refers to my claim that sermons were above all communication channels, which framed and presented the process of entering a convent and could substantially affect how audiences came to understand these events. ${ }^{3}$ Using specific

\footnotetext{
${ }^{1}$ This paper was originally written for the American Historical Association Annual Meeting in Boston in 2011 as part of the panel "Convents and Canonries in the Counter-Reformation: Three Central European Examples." My participation at the conference was enabled by two grants: the internal grant of the Silesian University in Opava, Nr. IGS/29/2011, and the postdoctoral grant of the Czech Science Foundation, Nr. P405/11/P510. I would like to express my thanks to Joseph F. Patrouch for his first proofreading of my text, to Janine Ch. Maegraith for her long-term support, feedback, and language checks, and to Christine Schneider for the insightful comments on the last version of my manuscript.

${ }^{2}$ In a strict sense, the term "monachization" refers to monastics, but because of the need of synonyms for convent initiation or entry, I use it in a broader sense. For this usage, see also Abigail Brundin, "On the Convent Threshold: Poetry for New Nuns in Early Modern Italy," Renaissance Quarterly 65, no. 4 (2012): 1125-65.

${ }^{3}$ For an attempt to systematize the approaches to the concept of framing and to suggest a coherent media framing theory, see Dietram A. Scheufele, "Framing as a Theory of Media Effects," Journal of Communication 49, no. 1 (1999): $103-22$.
} 
examples, I will demonstrate in this article how the sermons framed their subjects for the public. The article pays particular attention to the chief characteristics of monachization sermons in order to place them on the research map and to facilitate further study and use of these documents. To encourage broader comparative research, I will occasionally refer to similarities and differences between these sermons and other comparable sources related to nuns' initiations and convent cultures. In the end, I will outline some possibilities for future research.

\section{The Context}

Early modern female religious communities in Central Europe have long been heavily underresearched, and the scholarly interest in them has not been systematic. The current state of this field contrasts to the vital scholarship on women's convents in Western Europe. Moreover, not much of the existing literature has been translated and is therefore rarely referenced by Western scholars. ${ }^{4}$

The early modern Central European religious landscape bears a number of significant features that make it different from Western and especially South Western Europe. Derek Beales has rightly asserted that the number of late-eighteenth-century monasteries and convents in the Habsburg territories was "paltry" in comparison with France, Italy, Spain, and Portugal. ${ }^{5}$ Important factors contributing to the lower density of convents were the lower density of both rural and urban populations, especially in East Central Europe, and the prolonged impact of various waves of reformations in Central Europe that often severely disturbed or interrupted the institutional continuity with the medieval period and complicated the conditions for recruiting new candidates. ${ }^{6}$ Moreover, early modern Central Europe was not only influenced by the Protestant reformation, but its eastern part was also deeply affected by the long period of Ottoman dominance. In the lands of the Hungarian Crown, for example, the ratio of regulars to the population was by far the lowest among the Catholic parts of East Central Europe. The network of institutions of regular life was very uneven throughout the Habsburg monarchy. Not surprisingly their concentration was higher in the centrally located duchy of Lower Austria. ${ }^{7}$ I focus on the Central European Habsburg territories, where the dissolution of monasteries initiated by Emperor Joseph II in the later eighteenth century brought about massive losses in the sources from the convent archives and libraries. Moreover, in the lands of the former Communist bloc, further extensive losses of written sources and artifacts occurred.

In the course of the post-Tridentine Catholic revival, several observant movements and new orders from Italy, Spain, and France were introduced into East Central Europe. However, few religious orders originated in Central or East Central Europe before the onset of the nineteenth century. As examples of locally formed religious institutions, one could mention various types of

\footnotetext{
${ }^{4}$ Silvia Evangelisti cites the limited accessibility of Eastern European literature as a reason for her preference to study early modern convent life in Western Europe and the Catholic parts of the Americas while leaving out Central and Eastern Europe in her recent synthetic monograph. Silvia Evangelisti, Nuns. A History of Convent Life, 1450-1700 (Oxford, 2007), 3.

${ }^{5}$ Derek Beales, Prosperity and Plunder: European Catholic Monasteries in the Age of Revolution, 1650-1815 (Cambridge, UK, 2003), 180.

${ }^{6}$ Cf. Jaroslav Miller, Urban Societies in East-Central Europe, 1500-1700 (Aldershot, 2008).

${ }^{7}$ Beales, Prosperity and Plunder, 180.
} 
communities of regulated Franciscan Tertiaries, which emerged in the eighteenth century and did not substantially expand to Western Europe. One could also cite a new women's teaching community of Franciscan Sisters founded by Maria Hueber (1653-1705) in Tirol around $1700^{8}$ or another teaching community, the so-called Franciscan Sisters of Hallein, which was established by Theresia Zechner (1697-1763) in the Archbishopric of Salzburg in the 1720s. ${ }^{9}$

Over the past two decades, however, the male religious orders of the early modern Habsburg monarchy have received considerably more scholarly attention than the communities of nunspartly because of the common assumption that there are not enough sources for serious research on religious women. In this context, it is particularly productive to broaden the range of employed sources and methods in order to enrich this area of research. In doing so it will also eventually be possible to put the existing scholarship on nuns' cultures in early modern Western Europe and the Americas into a much broader perspective. ${ }^{10}$

\section{Placing Individual Nuns at the Center?}

The aim to find individuals behind historical processes and structures has been part of a longterm effort in Central European Historical Anthropology. With this aim came the problems of locating self-determining actors rather than represented and idealized individuals. ${ }^{11}$ The monachization sermons do not as such make the nuns directly accessible to researchers as historical actors; rather, they represent the celebratory discourse of early modern female regulars. In this section I address this epistemological tension.

As the religious orders traditionally placed more emphasis on the community as a whole than on its individuals, the surviving sources that were written by or that concern individual regulars are consequently quite scarce. The common practice of members of the male branches of their orders or local bishops supervising the female convents did not encourage female authorship but rather gave rise to texts about female communities penned by male clergy. Only in some rare cases have the narrative texts authored by women survived in the lands of the former Habsburg monarchy. These include, for example, the necrology and the chronicle of the

\footnotetext{
${ }^{8}$ On Maria Hueber recently, see Eva Cescutti, "Mädchenschule und Frauenkongregation: Maria Hueber 'revisited', in Frauenklöster im Alpenraum, ed. Brigitte Mazohl and Ellinor Forster, 153-68 (Innsbruck, 2012).

${ }^{9}$ On the rise of the community of Franciscan sisters of Hallein, see Christine Gigler, "Die Entstehung und innere Organisation der Kongregation der Halleiner Schwestern-Franziskanerinnen im 18ten Jahrhundert," in Between Revival and Uncertainty. Monastic and Secular Female Communities in Central Europe in the Long Eighteenth Century / Zwischen Aufbruch und Ungewissheit. Klösterliche und Weltliche Frauengemeinschaften in Zentraleuropa im „langen“ achtzehnten Jahrhundert, ed. Veronika Čapská, Ellinor Forster, Janine Maegraith, and Christine Schneider, 219-40 (Opava, 2012). The examples stated above are limited to the Habsburg lands. For a broader overview of female religious institutions that originated in Central Europe, see Veronika Čapská, "Between Revival and Uncertainty: Female Religious Life in Central Europe in the Long Eighteenth Century," in Between Revival and Uncertainty, 16-19.

${ }^{10}$ Moreover, there have recently appeared significant contributions to the research on women religious in the early modern Polish-Lithuanian state and in Russia. Cf., esp. Małgorzata Borkowska, Zakony żeńskie w Polsce w epoce nowożytnej [Female Religious Orders in Poland in the Modern Period] (Lublin, 2010); Andrzej Radzimiński, Dariusz Karcewski, and Zbigniew Zyglewski, eds., Sanctimoniales. Zakony żeńskie w Polsce i Europie Środkowej (do przełomu XVIII i XIX wieku) [Sanctimoniales. Female Religious Orders in Poland and Central Europe (until the Turn of the Eighteenth and Nineteenth Centuries)] (Bydgoszcz/Toruń, 2010). On convents in Eastern Orthodox Christianity, cf. Angelika Schmäling, Hort der Frömmigkeit-Ort der Verwahrung. Russische Frauenklöster im 16.18. Jahrhundert (Stuttgart, 2009).

${ }^{11}$ Cf. Richard van Dülmen, Historische Anthropologie: Entwicklung-Probleme-Aufgaben (Cologne, 2001).
} 
convent of Viennese Ursulines, which have recently been analyzed by Christine Schneider. ${ }^{12}$ However, for the majority of convents in East Central Europe no extensive narrative texts written by women are known to have been preserved.

There are also only rarely preserved ego-documents such as private journals, autobiographies, personal correspondence, and so forth. ${ }^{13}$ In the search for sources that place individual nuns in the center of attention, the sermons on the occasion of entering a convent represent rich narrative sources that deserve careful analysis. These multifaceted texts convey ample gendered meanings. For example, they abound in nuptial imagery and often conceive a spiritual union as hetero-normative, relating it to the socially compulsory model of relationships. ${ }^{14}$ Another example of a promising field for gender analysis is the study of literary ventriloquism, that is, a literary means by which the author appropriates someone else's voice. It was a common practice of preachers that, besides using their own voices, they would occasionally adopt the nuns' voices in the first person, thus speaking/writing on the nuns' behalf while creating the illusion of women's self-expression. ${ }^{15}$

The sermons also reveal the place of individual women within family strategies and convent practices in early modern Central Europe. Women who entered a religious vocation were quite frequently omitted from premodern family genealogies, as they usually did not bear any children to reinforce the continuity of official family tradition. The preserved printed sermons thus draw attention to family members who were otherwise often unknown or hardly known from the materials of various family archives. ${ }^{16}$ The printed orations frequently contain genealogical details and embed the respective nuns in historical memory. Occasionally they indicate alternative genealogies of kinswomen in one religious institution and enable us to trace related female family members in official family trees. These relationships are otherwise barely noticeable. Sometimes one can even learn parts of the life

\footnotetext{
${ }^{12}$ Christine Schneider, Kloster als Lebensform. Der Wiener Ursulinenkonvent in der zweiten Hälfte des 18. Jahrhuderts (1740-1790) (Vienna/Cologne/Weimar, 2005), 132-33. More recently, Schneider, "Vom Leben und Sterben im Kloster. Biografische Notizen in der Konventchronik und im Nekrolog des Wiener Ursulinenklosters," in Leben und Alltag in böhmisch-mährischen und niederösterreichischen Klöstern in Spätmittelalter und Neuzeit, ed. Heidemarie Specht and Tomáš Černušák, 212-30 (St. Pölten/Brno, 2011); Schneider, “Zu Nuzen, Trost und Unterricht aller nachfolgenden [...]'-Die österreichischen Ursulinenchroniken im 18. Jahrhundert,” in Frauenklöster im Alpenraum, 65-90. A markedly larger number of texts authored by women religious are preserved for the Holy Roman Empire, especially Bavaria. See, for example, Charlotte Woodford, Nuns as Historians in Early Modern Germany (Oxford, 2002).

${ }^{13}$ For nuns' letters, cf. Christine Schneider, "Briefe von Nonnen als Quelle für die Analyse familiärer Netzwerke: Die Augustiner Chorfrau Isabella von Thürheim (1663-1723)," Mitteilungen des Instituts für Österreichische Geschichtsforschung (forthcoming). Eva Kormann has drawn attention to autobiographical aspects of nuns' chronicles from seventeenth-century Germany. Eva Kormann, Ich, Welt und Gott: Autobiographik im 17. Jahhundert (Cologne, 2004), 186-226.

${ }^{14} \mathrm{~A}$ similar phenomenon can be observed in hagiographic literature. Cf., recently, Lucie Storchová, "Gender a 'přirozený řád' v českojazyčných diskursech vdovství, panenství a světectví raného novověku [Gender and the 'Natural Order' in the Czech Language Discourses of Widowhood, Virginity and Sainthood in Early Modern Period]," in Nádoby mdlé, hlavy nemající. Diskursy panenství a vdovství v české literatuře raného novověku [Weak Vessels without Heads? The Discourses of Virginity and Widowhood in Early Modern Czech Literature], ed. Jana Ratajová and Lucie Storchová, (Prague, 2008), 538.

${ }^{15}$ On the literary ventriloquism as an instrument of the "larger cultural silencing of women," see Elizabeth D. Harvey, Ventriloquised Voices: Feminist Theory and English Renaissance Texts (New York, 2005), 12-13. For an analysis of ventriloquization in monachization poems from early modern Italy, see Brundin, "On the Convent Threshold," 1140-45.

${ }^{16}$ On the invisibility of nuns in family genealogies, see, for example, Elissa B. Weaver, Convent Theatre in Early Modern Italy: Spiritual Fun and Learning for Women (Cambridge, UK, 2002), 2.
} 
stories of these individual nuns. For example, when the noblewoman Maria Theresia Salomena Bechinie von Laschan (Bechyňová $\mathrm{z}$ Lažan) took the veil in the Ursuline convent in the New Town of Prague in 1720, the preacher recalled that she had first been a boarder or "Kostfrau" in the Ursuline convent. Later she returned to her elderly parents to care for and assist them in the last stages of their lives. Only after they had passed away did she take the habit of the Ursuline nuns. ${ }^{17}$ Given the eulogic character of the monachization sermons, by including this episode the preacher also highlights such practice as praiseworthy. Another sermon on convent entry is built on the difference between quiet convent life and the previous constant mobility of the entrant Anna Theresia von Germeten, daughter of a high official in the Habsburg services, Bernhard Heinrich von Germeten. She had followed her father at an early age from Vienna to Prague, later back to Vienna and farther to Pressburg (now Bratislava) before she joined the Ursuline community in the castle district in Prague. ${ }^{18}$

The textual position of women regulars in the analyzed sermons oscillates between centrality and marginality. Male authorship, family interests, and priestly definitions of the ideals of convent life seem to have functioned as the chief coordinates that determined the place occupied by the individual nuns in the homiletic texts.

\section{Characterization of the Sources}

Before I move on to operationalize the concepts of communication and framing, let me introduce and characterize the sermons on convent entries and related sources. The monachization sermons are preserved in large numbers in Central European library collections and archives-both state and private ones. No systematic catalogue or survey exists, however, that records these sermons. ${ }^{19}$ So far I have been working with a sample that relies on major state library collections throughout Central Europe and on the rich collection of the Premonstratensian Strahov Monastery Library in Prague. ${ }^{20}$ The sermons in question could be defined as orations delivered at the festivities, which did not follow from the course of the liturgical year but were organized by convents or orders on specific occasions and were closely related to their own operations. Because of this circumstance, they differ profoundly from common sermons universally usable from every pulpit during various stages of the church year and are thus of particular interest for the research of female religious. As the Thirty Years' War faded and the process of confessional transformation in the Habsburg monarchy advanced, female religious life in Central Europe gained new vitality. It became increasingly popular to publish the sermons delivered on the occasions of

\footnotetext{
${ }^{17}$ Florianus Weidinger, Der Fisch in seinem Wasser sittlicher Weiss: Das Hertz in seinem Vergnügen. Der hoch-edelgebohrnen Fräule Maria Theresia Salomena Bechinie von Laschan: welche ... Ihre uralte adeliche Stammfisch auss diesem argliftigen Welt-Meer in die ausserlesneste Brunnen dess Heylands ... übersetzet.... (Prague, [1720]). The sermons often lack pagination, or their pagination may vary in various preserved exemplars, as they are often bound in larger collections. However, they are usually no longer than ten to twenty pages, and I therefore cite them without referring to specific pages.

${ }^{18}$ Friedrich Kauschke, Der beste Theil auf Erden Das Vergnügte Leben in dem Geistlichen Ordenstand ... Heunt angefangen von ... Anna Theresia Constantia von Germeten ... Bey Hochzeitlichen Eintritt (Prague, 1738).

${ }^{19}$ In general, little cataloguing according to the various types of the abundant baroque sermons has been conducted so far. A rather exceptional example is provided by Werner Weltzig et al., eds., Lobrede: Katalog deutschsprachiger Heiligenpredigten in Einzeldrucken aus den Beständen der Stiftsbibliothek Klosterneuburg (Vienna, 1989).

${ }^{20}$ The Strahov librarian Hedvika Kuchařová especially has developed an in-depth knowledge of the monachization sermons, and I am grateful to her for long-term help and support.
} 
formal entry into the female convents. This leads to the assumption that the printed orations also functioned as instruments to draw attention to the renewal of the old convents and the rise of new religious institutions.

In the Habsburg monarchy the popularity of the printed sermons on the occasion of entering a convent emerged in full force in the 1660s and 1670s. They remained extraordinarily popular well into the 1750s and continued to be printed even later. Early sermons from the last third of the seventeenth century concerned mostly noble candidates. Later, especially in the course of the eighteenth century, texts related to women of burgher origin also appeared. This development followed a general change in convent structure as established in the historiography. ${ }^{21}$

Some printed sermons focused on the festivity of entering into the enclosure and receiving the religious habit, two events that might have occurred on the same day but could also have been celebrated separately. Other sermons commemorated the act of taking the vows. All three events were regarded as the various stages in the life of a woman as a novice or a professed nun, leaving the secular world behind and beginning a new phase. Sometimes a published oration from one of these occasions survives; at other times there is both a sermon commemorating the entry into the novitiate and a sermon celebrating the religious vows of one particular nun (or a group of nuns).

Although the orations celebrating the entry into a convent represent the most common type of sermon related to a convent milieu, special occasions for holding sermons in convents were diverse and there were other events popularly acclaimed in sermons, such as the anniversary of a foundation or of the papal approval of a religious institution or the festivities celebrating patron saints of a particular order or house. There were also sermons on miraculous images and statues venerated in various convents. Related to the type of sermons on entering a convent are the orations honoring the fiftieth anniversary or golden jubilee of the vows, which usually concerned former or current superiors. They also focus on individual nuns, but these particular sermons were exceptional given that few early modern nuns reached the age of the golden jubilee of the religious profession. Another special event celebrated in a printed sermon could have been the installation of the abbess, probably one of the most glamorous festivities in a convent. One such oration, well known in earlier scholarly literature, was a sermon commemorating the coronation of the abbess Františka Helena Pieroni da Gagliano, from the famous family of Italian architects, in the Benedictine abbey at the Prague castle on 25 November 1691. Part of the ritual of the presentation of the new abbess of the oldest monastic institution in the lands of the Bohemian Crown was the coronation of the new superior by the Prague archbishop. With her ascent to the office, the superior gained the honorary title of princess-abbess and the right to crown the queen of Bohemia. ${ }^{22}$ Quite atypically, the above-mentioned sermon was printed in Czech. Such sermons in Czech became increasingly rare toward the end of the seventeenth century as the process of

\footnotetext{
${ }^{21}$ For the territory of the Habsburg monarchy, cf., for example, the case of the Benedictine nunnery in St. Georgen am Längsee in Carinthia. Christine Tropper, "Die Entwicklung des Konventes des Benediktinerinnestiftes St. Georgen am Längsee im 18. Jahrhundert," in Between Revival and Uncertainty, 183-202.

${ }^{22}$ Adam Ignác Mladota of Solopisky, Humilitas exaltata et virtus coronata. Poníženost vyzdvižená a ctnost korunovaná ... při slavnosti korunování a štastného uvádění ... panny Františky Heleny Pirony z Galliano... [Humilitas exaltata et virtus coronata. The Exalted Humility and Crowned Virtue... at the Festivity of Crowning and Happy Introducing...of the Virgin Franziska Helena Pieroni da Gagliano] (Prague, 1691). The sermon has already attracted the attention of nineteenth-century scholars. Cf. Josef Jireček, Rukovět k dějinám literatury české do konce XVIII. věku ve spůsobě slovníka životopisnéhoa a knihoslovného [Manual to the History of Czech Literature until the End of the Eighteenth Century in the Form of a Biographical and Bibliographical Dictionary], vol. 2, (Prague, 1876), 42. Ottův slovník naučný [Otto's Encyclopedia], vol. XVII (Prague, 1999), 451-52.
} 
centralization of the Habsburg monarchy proceeded. ${ }^{23}$ Moreover, in the seventeenth and eighteenth centuries, the convents were often renewed or founded with the assistance of German-speaking nuns. Although there were sermons printed in other vernacular languages and in Latin, the vast majority of orations related to female convents are written in German.

Out of the various types of sermons connected with female convents, the printed orations related to the process of entry into the religious community were the most common. The high number of preserved examples allows me to opine that they became a fashionable phenomenon in the late seventeenth and the first half of the eighteenth centuries. Some preachers clearly enjoyed a reputation for preaching on the occasions of convent entries and professions. They became specialists in the genre and were often entrusted with the task of delivering and writing a speech. Whereas some orators were members of male branches of respective religious orders or convent confessors, others like the Prague Jesuit Johann Steiner, for example, were specifically invited by the Ursulines and the Order of St. Elisabeth, as well as by the Annunciation nuns. ${ }^{24}$

Presumably to reduce the costs, sometimes sermons for several young nuns-to-be were published together. This was more common when candidates were from the burgher milieu and may have been more popular with strict religious orders, notably the Poor Clares. ${ }^{25}$

\footnotetext{
${ }^{23}$ A less-known Czech language sermon survives on the installation and coronation of the preceding abbess, Anna Mechtilda Schönweiss of Ebenstein. This sermon was delivered by Jan Ignác Dlouhoveský of Dlouhá Ves on 10 January 1672. Cf. Jan Ignác Dlouhoveský of Dlouhá Ves, Zrost aneb prospěch dvanáctiletého $v$ chrámě jeruzalémském učitele Krista Ježíše. To jest ř č ... Na slavnost korunování a štastného uvádění kněžny panny Anny Mechtildy Šnvejsové z Ebenštejna ... [The Accomplishment of a Twelve Year Old Teacher Jesus Christ in the Temple of Jerusalem. That is a Speech...on the Festivity of Crowning and Happy Introducing of the Princess Virgin Anna Mechtilda Schönweiss of Ebenstein...] (Prague, 1672).

${ }^{24}$ Martin Warell served as a Confessor in the convent of Sonnenburg, as is imparted in the title of the following sermon: Martin Warell, Geistliches Sonnen-Blümlein in dem hoch-adelichen Convent-Garten dess fürstlichen Stiftts und Hoch-würdigen Frauen-Closters Sonnenburg durch Ablegung der H. Profession und Ordensgelübt Frauen Maria Theresia von Rost ... von dem hoch-ehrwürdigen hochgelehrten Herrn Marttin Warell dess hochwürdigen Collegii Canonicorum Lateranensium zur Neu-Stifft gewesten Decano der mahlen aber Pfarrherrn zu Pfaltzen und hochgedachten Fürstlichen Stiffts Sonnenburg Beicht-Vatter (Innsbruck, 1692). Cf. also some examples of homiletic work of Johann Steiner, Der in den Himmel übersetzte Stern, die Hoch- und Wohlgebohrne Fräule Maria Anna Gräfin von Sternberg ... (Prague 1735); Steiner, Die Sonn unter der Wolcken, und der Morgenstern in dem Nebel ... Als die ... Maria Anna Gräfin von Sternberg ... Ihren ... Stammenstern unter das Gewölck deß schwartzen Ordenskleyds ... verborgen hat ... (Prague 1737); Steiner, Glückseeligste Hochzeit mit dem himmlischen Gespons der ... Anna Veronica Mathiassin des ritterlichen Geschlechts von Glauchowa ... als selbte durch feyerliche Ablegung deren heiligen Ordensgelübden sich mit einem dreyfachen Band der Lieb mit Christo vermählet in dem heiligen Orden der heiligen Elisabeth ... (Prague, 1736); Steiner, Gott mit dem Mensch, und der Mensch mit Gott durch die Absönderung von der Welt: als ... Fräule Josepha aus dem ritterlichen Geschlecht Losy von Losenau den ... Orden von der Verkündigung, oder insgemein Coelestinerinnen genannt, eingegangen ... in der königlichen Neustadt Prag (Prague, 1740).

${ }^{25}$ Cf. Benno Hupp, Schwannen Flug und Flucht, oder Welt-Beuhrlaubendes Vale: So Drey, Trewe Gott gewidmete Jungfrauen bey Antrettung deß H. Clarae Ordens nach sterbender Schwannen-Art gesungen; in Ertz-Hertzoglichen Jungfräulichen Clarissen Stifft zu Grätz, bey Aller Heiligen genandt (Vienna [1687]); Gabriel Poltzer, Die beschuldigte denen Peynigern uberantwortete Treue Unschuld und unschuldige Treu. Da drey edle und tugendreiche Jungfrauen ... bey ihrem ersten Eintritt in den jungfräulichen Orden ... S. Clarae ... auf ein ganzes Jahr in dasiges Clösterliche Zucht-haus, und Novitiat verurtheilet und überantwortet worden ... (Opava, [1744]); Poltzer, Drey verliebter frey beliebter, und Treu verübter von göttlicher Justiz geliebter Kirchen-raub. Da drey ... geistl. Jungfrauen ... durch solemne Profession dieses heil. seraphischen und jungfräulichen Ordens-stand zum angenehmsten Feuerstodt der Göttlichen Liebe... verurtheilet worden (Opava, [1745]); Gregor M. Zinck, Wahre Glückseeligkeit oder Himmel auf Erden im geistlichen Ordens-stand, wohien bey glücklichen Eingang in den Orden der heiligen Clarae seynd eingeführet worden vier edle Jungfrauen: Maria Anna Kocianin, Anna Barbara Schubertin, Cäcilia Weinmannin, Elisabetha Hefstreitin ... (Prague, [1752]).
} 
Another significant opportunity to save money occurred when candidates related by blood entered the same community. For example, this was the case of two sisters from the noble family of the counts of Cavriani, Franziska and Maria Anna, who received their habits in the convent of Viennese Ursulines on 10 January $1754 .{ }^{26}$ Such situations also enabled families to display a special degree of "pietas." Georg Sebastian Petschik captured a rather unusual case in his sermon on the occasion of a joint celebration of the profession of Theresia Rachlitz and the first mass of her newly ordained brother Franciscus Rachlitz. The sermon presents their father as an exemplary parent ready to dedicate his children to God: "Could the father who is now of a quite advanced age have experienced a greater joy in his children?"27

Given the similar character of celebrations of nun entries and jubilees, as was mentioned above, these festivities were sometimes joined and demonstrated an interesting potential both to honor the beginning of a life in a convent and the perseverance in religious vocation. The Dominican preacher Lorenz Brückner delivered a speech in the Dominican convent in the Old Town of Prague celebrating the first vows of Maria Elisabetha countess of Salm and the golden jubilee of Magdalena Lucia Hýzerlová of Chodov in $1717 .^{28}$ Similarly, a Viennese Servite Johann Maria Minetti composed a sermon on the occasion of the celebration of the fiftieth anniversary of the vows of Sister Angelina and the reception of the habit by two young candidates in the convent of Elisabethan sisters in Bratislava (then Pressburg/Pozsony) in $1797 .^{29}$ Unfortunately, we usually lack sources that reveal explicitly who financed these mixed sermons. We may, however, hypothesize that financial reasons were generally at play, together with the attractive opportunity to celebrate jointly the embracing and constant adherence to religious vocation or, as in the case of siblings, to display an exceptional family piety.

Let me now outline briefly the prototypical structure of the monachization sermons through one specific example: the oration delivered for Franziska Anna countess Sweerts-Sporck on the occasion of her vestition in the convent of the nuns of St. Elisabeth in Prague on 3 February 1732. The titles of sermons often reveal or indicate the overall concept that unifies the content of the sermon. In this case, the Servite preacher Victorinus Maria Romacker conceived his oration as a defense in the legal case of a falsely accused innocent young nunto-be: "The blackened innocence accused by the mighty enemies of the soul, the world, the flesh and Satan, defended by a strong following, with God as an impartial protector of Daniel's innocence."30

\footnotetext{
${ }^{26}$ Joseph Pohl, Rede, da in höchster Gegenwart deren Kayserlichen Mayestäten Francisci I. und Mariae Theresiae die feyerliche Einkleidung deren hochgebohrnen Fräulein Schwestern Gräfinnen Franciscae, und Mariae Annae von Cavriani ... vorgegangen (Vienna, 1754). For the reference to this sermon, I am indebted to Christine Schneider.

27"Hätte wohl der nunmehro in denen Jahren ziemlich hoch gestiegene Herr Vatter an seinen Kindern eine größere Freud erleben können?" Georg Sebastian Petschik, Theresia von der Liebe Gottes, und Franciscus von der Liebe der Nächsten, Beyde gebohrne Rachlitzen, Geschwister von Geburth, Geschwister in der Liebe, Geschwister in der Seeligkeit ... (Prague 1744).

${ }^{28}$ Laurentius Brückner, Pforten dess Himmels ... Zu dem heiligen Gnad- und Jubeljahr auffgerichtet ... Als Febronia Josepha Cordula a SS. Trinitate, Hochgebohrne Magdalena Lucia Ludmilla Freyin Hiserlin von Chodau ... Ihre anderte heilige Ordensgelübdprofession ... wie auch die ... Jungfrau ... Maria ... hochgebohrne Gräffin Salm ihre erste Profession ... (Prague, 1717).

${ }^{29}$ This late-eighteenth-century sermon is already very sober in its title, contrasting with orations of the baroque period. Cf. Johann Maria Minetti, Predigt bei Gelegenheit einer zweyten Ordensprofess und zwoer Einkleidungen, gehalten in der Kirche der wohlerwürdigen Klosterfrauen der heiligen Elisabeth, zu Pressburg, am Festtage Maria Himmelfahrt ([Bratislava], 1797).

${ }^{30}$ Victorinus M. Romacker, Die Verschwärtzte, und von denen mächtigen Feinden der Seelen, der Welt, dem Fleisch, und dem Satan beklagte Unschuld, durch starcken Anhang, mit Gott vertheidiget von einem unpartheyischen Beschützer der Unschuld Danielis ([Prague, 1732]).
} 
The sermon has no dedication to a powerful patron, which is sometimes inserted between the title page and the actual text and testifies to its social networking function. Nonetheless, the title page contains another socially relevant reference as it mentions that the vestition was performed by the Prague archbishop Joseph Daniel von Mayern.

The text of the sermon is visually introduced by a frieze with the Sporck family coat of arms flanked by the allegorical figures of Justitia and Veritas. They serve the family representation and also form the visual pendant to the preacher's appeals to justice and truth as he figuratively acts as Franziska's defense lawyer in the case following the example of Daniel from the Old Testament who defended the falsely accused Susanna. Here the name of Daniel also constituted a wordplay on the name of the Prague archbishop Joseph Daniel von Mayern.

The text of the sermon opens with a biblical quotation that provides a central theme that is further developed and serves as a refrain in the course of the whole oration: "But it is good for me to adhere to my God" (Pss. 72, 28) -an apt quotation for the event that celebrates an act of decision to stay near God as a nun. ${ }^{31}$

To various extents, preachers also addressed the so-called personalia at certain points in the sermon. Victorinus M. Romacker is brief in this respect. He only announces that Franziska is: "the sole most beloved daughter of her noble parents." 32 Whereas the personalia part established the candidate as a specific person within her family ties, the occasionally employed ventriloquized voice could draw attention to the paradox of the nun's silence and ascribed selfexpression. In the sermon, for example, Romacker asks Franziska what it is that makes her leave the world that abounds with so many luxuries and he answers the question for her using her voice in the first person and above all, referring to yet another authority-the Bible: "I can already hear the magnanimous answer of our bride dedicated to Our Lord: No! No! World, do not make too much of the Earth as I have considered this carefully and have seen that the earth is entirely vacuous (Jerem. 4 v. 23). So you, o vacuous world, cannot take pride in any plentitude." 33

The second part of a sermon may include an appeal to the community to accept the new nun. Romacker turns to the superior and the community of sisters on behalf of Franziska, appropriating her voice again: “Oh, Reverend mother superior, venerable religious sisters, please let me in!"34

The effort to publicize a specific religious institution is illustrated by the occasional passages that describe everyday life in a convent or the activities of a particular order, especially with the new communities of Elisabethan sisters or Ursulines who differed from older institutions in their engagement in nursing and teaching. Romacker included the following passage: "Let this religious house be a well-ordered school of love, in which not only the perfect love of God is perceived, but also the daily exercise of compassionate love to your neighbors is practiced; where one lifts and cares for the sick, feeds them, makes their beds; where one has to suffer much hardship and bad odor out of pure love, indeed, frequently with dangerous diseases one becomes a burnt offering of love pleasing in the sight of God." ${ }^{35}$ Such passages

\footnotetext{
31“Mihi autem adhaerere Deo, bonum est/Mir aber ist gut Gott anhangen.” Romacker, Die Verschwärtzte.

32“einzige liebste Tochter ihrer hochgräflichen Eltern.” Romacker, Die Verschwärtzte.

33“ Da höre ich schon von unser Gott gewidmeten Braut die großmüthige Antwort: Nein! Nein! Welt mach nicht zu viel aus deinem Erdenkreis, denn ich habe solche wohlbedächtig betrachtet, und habe gesehen, daß die Erde ganz leer ist. Aspexi terram, et ecce vacua erat (Jerem. 4 v. 23). Also kanst du dich, o leere Welt keine Völle rühmen.” Romacker, Die Verschwärtzte.

34“Ach, aperi mihi soror mea! Hochwürdige Frau Mutter, Wohl-Ehrwürdige geistliche Schwestern, machet mir doch auf!” Romacker, Die Verschwärtzte.

35“Dieses geistliche Stifft sey eine wohlgeordnete Liebes-Schule, in welcher nicht nur allein die vollkommene Liebe Gottes erkennet, sondern auch tägliche Exercitia in Übung der mitleidigen Liebe gegen den Nechsten an die Hand
} 
clearly aimed at the wider public because the convent community, the candidate, and her family were well acquainted with the activities of a particular religious institution.

In his conclusion, Romacker emphasizes that the archbishop takes the young candidate under his protection and brings the legal metaphor for the last time to the attention of his listeners/readers: "Thus I draw to a close and conclude my defense." 36 The sermons often close with a formal farewell to the world, to the candidate's parents and relatives. Romacker did not follow this convention, but he made use of another popular practice as he expressed his best wishes to the spiritual bride: "For this spiritual act of godly vestition I ask for God's grace and assistance!" 37 Visually, the sermon closes with a vignette that depicts the coat of arms of the Sweerts-Sporck family and the allegorical figures of justice and charity.

A rich variety of other sources about the Sporck and Sweerts-Sporck families make it clear that many important circumstances of Franziska's convent entry remained unacknowledged in the sermon. She came from a family with a long tradition of a strong attachment to religious orders-her aunt Maria Eleonora Sporck was an Annunciation nun and her mother Anna Catharina Sweerts-Sporck had also expressed a desire to take the veil and become a Benedictine nun. Because, however, the family had produced no male offspring, she was forced to marry by her father. Nonetheless, she and her husband later became tertiaries and major patrons of the order of Servants of Mary (Servites), the order from which the preacher was invited to deliver a sermon commemorating their daughter's vestition. Also omitted from the sermon was the significant circumstance that Franziska had a brother who was an heir of the family estates and her own role in the family memory was thus only secondary. However, her convent entry continued the family tradition of building close ties with various religious orders. ${ }^{38}$

There may have been differences between vestition and profession sermons, but in general their structure is similar. Above all, the preachers may have chosen to follow the conventions or they could have decided to structure their sermons more individually, but they always had to meet the expectations of their patrons. When interpreting the sermons, it is important to keep in mind that preachers emphasized some aspects of the convent entry while omitting others, thus framing the event and shaping it for the audience and for posterity.

\section{Sermons as Means of Communication and Framing of Convent Entries}

As one of the key early modern channels of communication, the sermon was the literary genre with which the majority of the population regularly came into contact and which affected large audiences including semiliterate or illiterate people. Research on early modern nuptial and

gegeben werden; da man die Krancken hebet und leget, ihnen die Speise reichet, die Lägerstätte zurichtet; da man aus purer Liebe viel Ungemach und üblen Geruch erdulden muß, ja öffters bey gefährlichen Kranckheiten zu einen Gottgefälligen Brandopfer der Liebe wird." Romacker, Die Verschwärtzte.

36“"so schreite ich zu den Ende und beschlüsse meine Vertheidigung." Romacker, Die Verschwärtzte.

37"Ich wünsche zu diesen Gott-wohlgefälligen geistlichen Ankleidungs-Actum die göttliche Gnade und Beystand!" Romacker, Die Verschwärtzte.

${ }^{38}$ More on the context, see Veronika Čapská, “A Publishing Project of Her Own-Anna Katharina Sweerts-Sporck as a Patroness of the Servite Order and a Promoter of Devotional Literature," Cornova. Revue České společnosti pro výzkum 18. století a Filozofické Fakulty Univerzity Karlovy v Praze [Cornova. Revue of the Czech Society for Eighteenth-Century Studies] 1, no. 1 (2011): 67-80. Čapská, "Jan Kristián Sweerts-Špork a František Girtler-na společné cestě mezi zbožností a ekonomickým zájmem [Johann Christian Swéerts-Sporck and Franz GirtlerTogether on a Journey Between Piety and Economic Interest]," Theatrum historiae 6, no. 9 (2011): 79-96. 
funeral sermons traditionally belongs to a prolific field that is anchored on the disciplinary border between history and literary studies. ${ }^{39}$ By contrast, homiletics (i.e., the art of preparing sermons and preaching) connected with early modern female religious institutions has received little attention. ${ }^{40}$ Although the occasional sermons related to female convents have long been overlooked, they represented an important medium for making the convents visible, and they provided a means to draw attention to the hidden world of nuns. This is particularly important because the convents' physical presence in towns and other localities was not so perceptible as a result of the reinforced post-Tridentine emphasis on enclosure. ${ }^{41}$ Sermons were communication channels that ran across the divide between convents and the outer world. They celebrated and popularized the ideal of female conventual life. Both spoken and printed sermons attracted attention to the particular convent and religious order.

The published orations also enable historians to explore the much wider phenomenon of spoken sermons that were delivered but are usually not accessible to scholars, because they were part of a now lost oral culture. Early modern oral performances are only available to us if they were written down and preserved. The use of print significantly increased the chances to preserve these speeches for posterity. Although the sermons intended for publication were usually revised and polished after delivery, they represent important vestiges of early modern oral culture, the culture in which the public delivery of a sacred speech was almost exclusively reserved to male religious experts. ${ }^{42}$

Both kinds of sermons related to the initiation of young nuns, that is the sermons celebrating the entry into the novitiate and the sermons honoring the taking of vows, delimit the probationary period in a religious community. The concept of framing is thus employed in this essay both in the metaphorical and analytical sense. Figuratively speaking, both kinds of sermons virtually frame the novitiate as the prolonged liminal stage of a young nun's initiation. At the metaphorical level, the sermons also function in a way similar to a visual image: They seize the event and commemorate the woman or women who were entering the convent. The concept of frames and framing can be used in accordance with Erving Goffman and other sociologists as the organizing structure that provides an authoritative interpretation. According to this approach, the media frame events. ${ }^{43}$ In our sense, the early modern sermons do the interpretive work. However, on yet another level, historians, too, do the interpretive work. The ritual of entering an early modern convent thus becomes accessible to us through the process of the double framing performed both by period actors and by current scholars.

\footnotetext{
${ }^{39}$ An important Central European center of systematic research, which is very active in publishing studies on early modern homiletics, is the Herzog August Bibliothek in Wolfenbüttel, Germany.

${ }^{40}$ For another study, see Veronika Čapská, "Misionářky mikrosvěta. Řeholní ideál v kázáních při příležitosti vstupu žen do olomouckých klášterů [Missionaries of the Microworld. Religious Ideal in the Sermons on the Entry to Female Convents in Olomouc]," in Olomoucké baroko. Proměny ambicí jednoho města [Olomouc Baroque. A City's Ambitions Transformed], ed. Martin Elbel and Ondřej Jakubec, 197-203 (Olomouc, 2010).

${ }^{41}$ See, for example, Elisabeth Lehfeldt, "Discipline, Vocation and Patronage: Spanish Religious Women in a Tridentine Microclimate," Sixteenth Century Journal 30 (1999): 1009-30, at 1010. "Yet the decrees of Trent required strict active enclosure of all solemnly professed nuns. A papal bull issued after the meeting of the Council, 'Circa pastoralis', extended this requirement to tertiaries and convents that had never included strict enclosure in their rule. Overall, the demand for enclosure was a measure that limited the autonomy of convents and severed their ties with the outside world. Even movements that had cultivated a more active life of service, like the Ursulines and the Daughters of the Visitation, were ultimately forced to adopt modified disciplines of enclosure."

${ }^{42} \mathrm{On}$ the transmission from the oral register to the written form and on interconnection between literacy and religion, see Jack Goody, The Interface between the Written and the Oral (Cambridge, UK, 1999), ix-xii.

${ }^{43}$ Erving Goffman, Frame Analysis (New York, 1974). More recently, Scheufele, "Framing as a Theory," $103-22$.
} 
Early modern sermons render the event of entering a convent meaningful, they offer the preferred reading of the event, and like picture frames, they focus attention by accentuating and suppressing certain information. The sermons do not portray the process of convent entry in its complex context. For example, they avoid the issues of entries conditioned by previous upbringing in a convent or of burdensome family economic situations that can sometimes be inferred from other sources. They set the event in preexisting cultural schemata in accordance with the established social norms and values and thus endow the interpretation with relative constancy. The scholars interpreting the homiletic texts have to be aware that they are highly repetitive and prescriptive. More importantly, the sermons not only reflected but also strengthened and reproduced the prevailing norms and conventions. At the same time their authors could and occasionally did display creativity and innovation, venturing deeper into the sphere of uncontrollable imagination. ${ }^{44}$

The framing theory holds that media set the frames of reference that people tend to use to interpret public events. Even active members of the audience are susceptible to conceive things within the offered frames. The reactions of the public are inaccessible to us as historians, but we can infer the objectives of the sermons. The printed orations belong to the subgenre of the emblematic sermon that remained very popular in Central Europe well into the middle of the eighteenth century and was characterized by wit, wordplay, emblems, and the evocation of visual imagery. In general, the aim of the emblematic sermon was to excite emotions and to move the people. ${ }^{45}$

The Czech literary historian and researcher in Baroque homiletics, Miloš Sládek, asserts that some types of occasional sermons, including the orations at ordinations of priests and entering convents, focus on the aesthetic impression and amusement rather than on instruction and pedagogy. Other types of occasional sermons, especially funeral sermons (which have probably been studied most thoroughly), tend to have moralizing and educational functions at their center. ${ }^{46}$ Sermons, however, are not the only existing media that popularized and framed the process of monachization. Other types of published literary production related to convent entries deserve equal attention, although their distribution throughout various parts of Catholic Europe seems to have been very uneven. So far, no systematic study of such works has been attempted, and the current state of research only allows for some preliminary remarks.

In a recent study, Abigail Brundin analyzed the more secular genre of poetry celebrating nuns' convent entries in early modern Italy. ${ }^{47}$ In particular she accentuated the role of the monachization poems in "alliance-building and social maneuvering." 48 In Central Europe, the practice of composing poetry to mark nuns' initiation ceremonies seems not to have been widespread, although the existence of monachization poems cannot be entirely excluded, especially for aristocratic and courtly circles. Nonetheless, one can hypothesize that

\footnotetext{
${ }^{44}$ On the tension between repetition and innovation, cf., for example, Susan C. Karant-Nunn, "'Fragrant Wedding Roses': Lutheran Wedding Sermons and Gender Definition in Early Modern Germany,” German History 17, no. 1 (1999): 25-40, at 26.

${ }^{45}$ Alexander Bitzel, "The Theology of the Sermon in the Eighteenth Century," in Preaching, Sermon and Cultural Change in the Long Eighteenth Century, ed. Joris van Eijnatten, 57-94 (Leiden/Boston, 2009), at 88-89.

${ }^{46}$ Miloš Sládek, ed., Svět je podvodný verbír aneb Výbor z českých jednotlivě vydaných svátečních a př́ležitostných kázání konce 17. a prvních dvou třetin 18. století [The World Is a Deceitful Recruiter or the Anthology of Czech Separately Published Occasional Sermons from the End of the Seventeenth and the First Two Thirds of the Eighteenth Centuries] (Prague, 2005), 15.

${ }^{47}$ Brundin, "On the Convent Threshold," 1125-65.

${ }^{48}$ Ibid., 1156.
} 
the direct and intensive confrontation with the Protestant reformations did not create convenient conditions for the cultivation of this quasisecular poetry. Other examples of printed literary pieces commemorating nuns' entry ceremonies are plays, again well documented for Italy, ${ }^{49}$ or published songs on the occasions of vestition and profession from the mid eighteenth century, preserved, for example, for the Maria Loreto convent in Salzburg. Although I have been able to trace only two songs from Central Europe, a nota bene remark in one of them contains instructions when to sing the stanzas and indicates that these "personalized" songs were an established part of the entry ceremonies for the Capuchin nuns of the third order of Saint Francis. ${ }^{50}$

These sources enabled me to draw some comparisons and parallels with respect to media presentation and framing of the monachization rituals. All of the cited sources commemorate the entry rituals of individual nuns. They set these singular events in prestructured frames and publicize them. Whereas both preserved songs for the vestition and profession were written in a simple, unpolished style and were probably distributed to the participants at the festivity so that they could join in the singing, the monachization poems and sermons show striking similarities in the ways they made the acts connected with convent entries visible to the public. Besides aiming at family and convent members, the sermons and poems were intended for distribution to prominent guests and local elites. However, one can also identify differences. Abigail Brundin has asserted that monachization poems were posted in the city's streets and could even decorate the walls of a church or a chapel. ${ }^{51}$ This practice is not known for printed sermons, although researchers in homiletics presuppose they might have been presented as gifts. Sometimes the texts were distributed already during the festivity, but more typically they were put into print and distributed after the delivery of the speech. ${ }^{52}$

In framing the process of monachization, the early modern preachers had their own routines and relied on patterns and examples in various collections of sermons. Which works served as seminal, authoritative, or inspiring have yet to be identified and thoroughly explored. In the following, I will attempt to formulate some preliminary hypotheses.

The German collections of sermons printed in the Catholic areas of the Holy Roman Empire seem to have enjoyed high receptivity in Central European Habsburg lands. One can, for example, mention the two-volume compendium on profession sermons Geistliches Rosen-Büschl compiled by the Dominican friar and professor at the university in Cologne, Albert Grünewaldt. His anthology contains a wide range of exemplary emblematic sermons, as the title page advertizes: "With many beautiful concepts (concetti), various comparisons, stories, symbols, and aphorisms which are anchored in the Holy Scriptures, holy fathers, and teachers." 53 Grünewaldt

\footnotetext{
${ }^{49}$ Cf. Brundin, "On the Convent Threshold," 1127. Elissa B. Weaver, Convent Theatre in Early Modern Italy. Spiritual Fun and Learning for Women (Cambridge, UK, 2002), 60-61.

${ }^{50}$ Geistliches Abchied-Lied auf den Eintritt der Jungfrau Maria Catharina Zezin in das hochlöbliche Frauen-Closter Maria Loreto zu Salzburg (Salzburg [1755]); Beschreibung oder Frolockungs-Gesang und Andächtige Liebs-Seufzer der geistlichen Jungfrau Braut Mariae Augustinae zur Zeit Ihrer gestlichen Vermählung oder heil. Profession (Salzburg [1755]). Both printed songs are housed at the Austrian National Library and accessible online: http://data.onb.ac. at/rec/AC10040911.

${ }^{51}$ Brundin, "On the Convent Threshold," 1127-29.

${ }^{52}$ Cf. Joris van Eijnatten, "Reaching Audiences: Sermons and Oratory in Europe," in The Cambridge History of Christianity, vol. 7 (Cambridge, UK, 2006), 131. Sládek, ed., Svět je podvodný verbír, 23.

${ }^{53}$ Cf. "mit vielen schönen in H. Schrift, HH. Vätern, Lehreren, wohl gegründten Concepten, unterschiedlichen Vergleichnussen, Geschichten, Symbolen und Sinnsprüchen.” Albert Grünewaldt, Geistliches Rosen-Büschl der jetzigen auffgewachsenen blühenden Jugend präsentiert... das ist: Einkleidungs- und Professions-Predigen, 2 vols. (Cologne, 1698-1700).
} 
covers sermons on the entry of both male and female candidates and provides a list of authorities he draws on and, above all, a well-arranged index of sermon themes and their content.

The location where copies of such collections of sermons were preserved in East Central Europe provides us with some hints regarding their reception and use in the territories of the former Habsburg monarchy. I will therefore outline the situation as far as the current state of cataloguing permits. Grünewaldt's compendium, for example, can be found in the Research Library in Olomouc (German: Olmütz). The remarks on the title page of one exemplar reveal that the book was owned by the Dominican friary of St. Michael in Litoměrice (German: Leitmeritz) in northern Bohemia and used by the friar Vincenc Schindler. ${ }^{54}$ Another copy bears a bookplate of Ignaz Johann Schäffert, the general preacher of the Dominican order. ${ }^{55}$ That compendium is also housed in the library of the Premonstratensian Canonry at Strahov in Prague, that is, a monastery that also supervised the female convent in Doksany (German: Doxan) in northern Bohemia and could thus have appreciated a mixed collection of sermons on male and female professions. ${ }^{56}$

The experienced orator Johann Adam Nieberlein (1662-1748), the auxiliary bishop in Eichstätt in Bavaria, composed a specialized collection of sermons with an exclusive focus on the occasion of nuns' professions published in Augsburg in 1734 with the title Aufmunterung des Geists. The collection features twenty-four sermons that are based on his orations delivered in female convents in Eichstätt and vicinity, namely seven in the Benedictine abbey of S. Walburg in Eichstätt, seven in the Augustinian canonry in Marienstein, four in the convent of Notre Dame sisters in Eichstätt, two in the Augustinian canonry of Marienburg, and two in the convent of Dominican sisters of St. Catherine in Augsburg. Two sermons do not identify a concrete place of delivery, but the variety of religious orders and themes introduced in the book allow us to suppose that Nieberlein took pride in the reputation he gained in the genre and composed his anthology as an exemplary one. Although Nieberlein carefully identified most of the convents where his speeches took place, he depersonalized the content, so that his texts could easily be employed as templates and modified for further use. And, indeed, this compendium can also be found in Prague-in the National Library. ${ }^{57}$ The extended title of his collection articulates very well the normative message of the monachization sermons about the expected behavior of female religious: "How a bride, who will be married with her celestial groom Jesus Christ during her profession, should behave, live, and serve God." 58 Besides the language accessibility of the collections of sermons printed in the Holy Roman Empire, another factor that contributed to the popularity of the genre was probably the influence from countries with especially vibrant early modern female religious cultures, most notably from France. This was especially the case in connection with the status of the French language as the European "lingua franca" and the attractiveness of French cultural models in the late seventeenth and eighteenth centuries. ${ }^{59}$

\footnotetext{
${ }^{54}$ The shelf mark in the Research Library in Olomouc is 995 313/1 (1) B.

${ }^{55}$ The shelf mark in the Research Library in Olomouc is 995 313/1 (1) A.

${ }^{56}$ The shelf marks in the Strahov Library are: BR IV 35, BR IV 36.

${ }^{57}$ Johann Adam Nieberlein, Aufmunterung des Geists, das ist: Geistliche Ermahnungen, oder Profess-Predigten... verfasset und abgeleget in verschidenen Gotteshäusern...durch...Johann Adam Nieberlein (Augsburg, 1734). The shelf mark in the National Library in Prague is 34 E 88.

58“Wie eine Braut, welche in der Profession mit Christo Jesu, den Himmlischen Bräutigamb vermählet wirdt, sich verhalten, leben und Gott dienen soll." Nieberlein, Aufmunterung.

${ }^{59}$ On French as the language of diplomatic and literate elites, see Peter Burke, Languages and Communication in Early Modern Europe (Cambridge, UK, 2004), 85-88.
} 
Because collections of printed convent entry sermons published in French or translated from French have survived in Central European libraries, we can assume that there was interest in obtaining the originals and in translating them and that they attracted the attention of the literate. The Department of Manuscripts and Rare Books of the Austrian State Library in Vienna, for example, houses the popular collection of orations by the renowned French preacher and Jesuit professor of rhetoric Charles de La Rue (1643-1725), which was published in a German translation by Ignaz Wurz (1731-84) with the title Gelegenheitsreden bey Einkleidung und Einweihung zum heiligen Klosterleben. As a professor of spiritual rhetoric (geistliche Beredsamkeit) at the University of Vienna, Wurz enjoyed the status of authority in the art of preaching in the Habsburg lands. In the translator's foreword, Wurz indicates that his German version of the book was published repeatedly in the course of the second half of the eighteenth century. ${ }^{60}$

Ignaz Wurz was also a practicing preacher himself. When analyzing the rituals of convent entry on the basis of the chronicle of the Viennese Ursulines, Christine Schneider focused on the case of Anna Maria countess Starhemberg, who took the veil on 22 April 1771. The sermons on the occasion of her vestition and later profession ceremonies were delivered by Ignaz Wurz, who also served as her spiritual father. ${ }^{61}$ This establishes that as a translator, theoretician of spiritual oratory, and practicing preacher in Vienna he played an important role in shaping the genre in the Habsburg lands. Since the second quarter of the eighteenth century there were nine female religious houses in Vienna. These were in close contact with court society and church elites and their culture, including the art of spiritual preaching, was in many ways trendsetting for the convents in other major towns in the monarchy. ${ }^{62}$

The Austrian State Library also has three French original editions of the collection Sermons Oraisons funebres et professions religieuses, which were authored by the famous French Oratorian Jean-Baptiste Massillon (1663-1742) who ranked among the most eminent French preachers of his time, together with Louis Bourdalou and Jacques-Benigne Bossuet. ${ }^{63}$ The Premonstratensian Strahov Monastery Library in Prague and the Moravian Library in Brno (German: Brünn) own the French edition of the above-mentioned collection by Massillon and its German translation Trauerreden nebst vier Einweihungsreden, which was repeatedly printed in Central Europe. ${ }^{64}$ The French collections of festive orations on the occasion of

\footnotetext{
${ }^{60}$ Karl de La Rue, Gelegenheitsreden bey Einkleidung und Einweihung zum heiligen Klosterleben (Graz, 1777). The shelf mark in the Austrian State Library is 7536-B.Adl Alt Mag. The exemplar bears a supralibros of the Benedictine abbey of St. Peter in Salzburg. For more on Ignaz Wurz, see Constant von Wurzbach, Biographisches Lexikon des Kaiserthums Östereich, vol. 59 (Vienna, 1890), 11-13.

${ }^{61} \mathrm{Cf}$. Schneider, Kloster als Lebensform, 47-54.

${ }^{62}$ Cf. Christine Schneider, "Die Auswirkungen der josephinischen Klosteraufhebungen auf den Wiener Ursulinenkonvent," in Between Revival and Uncertainty, 131-54. The interconection of the convents with the court milieu is also well illustrated by Christine Schneider, "Briefe von Nonnen." The situation of convents in smaller towns on the periphery of the Habsburg monarchy might have been very different, and they were not very attractive for the well-to-do candidates as can be inferred from the comment of the nun of St. Elisabeth from Teschen in Upper Silesia: "und nacher Teschen darfen wir uns wenig Hoffnung machen eine reiche zu bekummen.” Cf. Land Archives in Opava, fond Královský úřad [Royal Bureau], sign. 15/ 53, cart. 667, A letter of Maria Aloisia from the Good Shepherd, dated in Teschen/Těšín/Cieszyn on 14 July 1779.

${ }^{63}$ Jean-Baptiste Massillon, Sermons. Oraisons funébres et professions religieuses (Paris, 1745, 1769, 1776). In the Austrian State Library the editions of 1745 and 1769 share the shelf mark 214331-A; the 1776 edition has the shelfmark 254967-A. On Massillon, see Françoise Deconinck-Brossard, "The Art of Preaching," in Preaching, Sermon and Cultural Change, 95-130, at 98.

${ }^{64}$ Jean-Baptiste Massillon, Sermons. Oraisons funébres et professions religieuses (Paris, 1770). The shelf mark in the Strahov Library is BU VIII 41; the Moravian Library in Brno houses the 1776 edition with the shelf mark SR 0000-236.
} 
entering a convent were thus apparently at hand for Central European preachers who could draw inspiration from them and creatively elaborate the genre.

However, it appears to have been the genre rather than its particular style that served as an inspiration for convent entry sermons. The French literary tradition of classical sermons differed substantially from the dominant Central European practice of emblematic sermons. In France, the classical sermon was developed by late-seventeenth-century preachers reacting against a baroque tradition that valued verbosity and evocation of visual imagery. In Central Europe, however, the tradition of baroque emblematic sermons enjoyed longer continuity. ${ }^{65}$

The collection of four orations by Massillon on the occasion of religious profession will now be examined. These seem to have belonged to the most widespread French examples of this type of sermon in Central Europe. They have a very general character, aim at encouraging a young female adept of conventual life, and could be easily adapted for specific situations. Unlike the separately published Central European sermons, the texts proper of these four French orations are followed by four sample content analyses that were probably intended to help less-experienced preachers compose their own texts for specific occasions.

The four sample sermons avoid hints of concrete situations, names of families, or nuns. Only in a footnote in the second sermon do we learn that it was pronounced on the occasion of the first vows passed in the new church of the Visitandine convent in Chaillot, a suburb of the city of Paris. ${ }^{66}$ The four orations focus on the relationship between God and the nun's soul, and the preacher turns especially to the young nuns-to-be rather than their families, the rest of the convent community, or other listeners/readers as is often the case in Central European emblematic sermons.

The first sermon develops the motto from the Book of Psalms: "He reached down from on high and took hold of me; he drew me out of deep waters ... and he brought me forth into a large place; he saved me because he was well pleased with me" (Pss. 17-20). The convent life is presented as a visible sign of God's election of a person, and a connection to the public character of religious vows is suggested. The sermon gradually introduces three types of comfort (consolation) provided by convent life. The first comfort consists in God's election of a person to whom God's hand has shown the way. The second comfort comprises God's preservation of a soul from the dangers of the outer world. The last comfort consists in assurance of sanctification and salvation. ${ }^{67}$

The second oration has a topic from the Psalms, well chosen for a first celebration of religious vows in a newly consecrated church: "How lovely is your dwelling place, o Lord of Hosts! My soul longs, indeed it faints for the courts of the Lord" (Ps. 83: 1-2). The oration is structured into two parts. The first one points out the temptations connected with convent life and the second one, again, draws attention to the comforts and opportunities provided by the life in a religious

Jean-Baptiste Massillon, Trauerreden nebst vier Einweihungsreden (Vienna, 1785-87). The shelf mark in the Strahov Library is BR II 52. The Moravian Library in Brno houses two earlier 1756 editions of the same German translation with shelf marks ST2-1255. 554, 9 (Dresden edition); CH 0005.600, 9 (Prague edition); and two 1786 editions with shelf marks ST2-1255.555, 9, A (Vienna edition); UB-0000.148, 9 (Vienna edition).

${ }^{65}$ See Thomas Worcester, "The Classical Sermon," in Preaching, Sermon and Cultural Change, 133-172, at 133.

${ }^{66}$ I have worked with both French and German editions of these four sermons. Although I have closely examined the editions published after 1748, i.e., six years after the death of Jean-Baptiste Massillon, the National Library in Paris houses in its collection the editions of sermons by Massillon, including a sermon on religious profession, from as early as 1708. Given Massillon's extraordinary fame, it can be assumed that his sermons circulated widely during his life. Jean-Baptiste Massillon, Sermons. Oraisons funébres et professions religieuses (Paris, 1748), 323; Massillon, Trauerreden nebst vier Einweihungsreden (Prague, 1756), 235.

${ }^{67}$ Massillon, Sermons, 271-321, 433-40; Massillon, Trauerreden nebst ... Einweihungsreden, 341-48. 
institution. Massillon distinguishes three types of temptations: the temptation of time as the young nun loses her initial zeal; the temptation of loss of fondness for religious life; and finally the temptation caused by the possible bad examples of other nuns. Among the comforts of religious life the preacher stresses, for example, the orderly life in which every moment is designed for a certain matter or the life in a community of sisters who care for one another. ${ }^{68}$

The third sermon is an excellent example of a speech that could be used on every occasion of taking religious vows. It contains three meditations on the three religious vows of chastity, poverty, and obedience, a very common pattern for this type of sermon. ${ }^{69}$ The religious vows are presented as a source of sanctification, which is at the center of the sermon following the initial quote from 2 Thessalonians: "This is the will of God: your sanctification" (2 Thes. 4: 3).

The last of the four exemplary sermons is introduced by a quote from Hosea: "I will betroth you to me forever; I will betroth you in righteousness and justice, in love and compassion. I will betroth you in faithfulness, and you will acknowledge the Lord" (Hos. 2: 19-20). This motto incites the preacher to dwell on the issue of the relationship between the nun's soul and God, a connection characterized by four features: righteousness, justice, mercy, and faith. It is this relationship that is publicly confirmed in the festivity of taking religious vows. ${ }^{70}$ The $^{2}$ same quotation was developed, for example, in the sermon delivered by the Jesuit Wilhelm Burchard on the occasion of taking religious vows in the convent of the Viennese Ursulines by Maria Sigismunda countess of Trauttmansdorff on 27 June $1743 .^{71}$

Although early modern sermons are often equipped with footnotes, the authors mostly quote the Bible and Patristic texts rather than admit inspiration from contemporary preachers. We can therefore only presume that working with available collections of sermons was a common part of the process of composing a new oration. A closer inspection of the circulation of themes and influences in narrative structures is a task for future research.

Early modern Catholic culture valued the power of the word, but unlike Protestant culture it also highly appreciated the visual in its manifold forms, one of the most complex examples of these being the spectacular festivities that combined word, image, and music. The sermons on the occasions of the entrance of nuns and jubilees enable us to explore the festivities connected with female convents and individual nuns. Because the emblematic sermons tend to make use of visual imagery and the preachers often comment on both the permanent and ephemeral decoration of the church interior and exterior, the texts enable us to analyze diverse aspects of the festivities. Sometimes the visual sources, such as a graphic sheet, can also be identified. An example is the print showing the ephemeral decoration and illumination of the high altar on the occasion of the golden jubilee of profession of the sister Maria Innocentia countess

\footnotetext{
${ }^{68}$ Massillon, Sermons, 322-67, 440-46; Massillon, Trauerreden nebst ... Einweihungsreden, 349-55.

${ }^{69}$ Massillon, Sermons, 368-405, 446-54; Massillon, Trauerreden nebst ... Einweihungsreden, 356-63.

${ }^{70}$ Massillon, Sermons, 406-32, 454-59; Massillon, Trauerreden nebst ... Einweihungsreden, 364-68.

${ }^{71}$ Guilielmo Burchard, Geistliche Vermählung mit Christo Mariae Sigismundae hochgebohrnen Fräule Gräffin von Trautmanstorff, bey feyerlicher Ablegung ihrer h. Ordensgelübden in dem Closter der heiligen Ursula in Wienn (Vienna, 1743). The celebratory discourse of sermons on convent entries did not allow preachers to form other than generally positive utterances about conventual life. However, other sources may impart to us the contents that sermons suppress. Christine Schneider has recently drawn attention to Maria Sigismunda countess of Trauttmansdorff and her two sisters who were violently taken in childhood from their Protestant mother and placed in a convent. All three grew up to become nuns, but one of them, Maria Anna, who took the veil with Benedictine nuns in Göss, Styria, at the age of 15, later regretted her forced entry and was considered to be mentally ill. Her sister, Ursuline Maria Sigismunda, wrote letters on her behalf explaining their childhood experience. Cf. Schneider, Kloster als Lebensform, 69-70.
} 


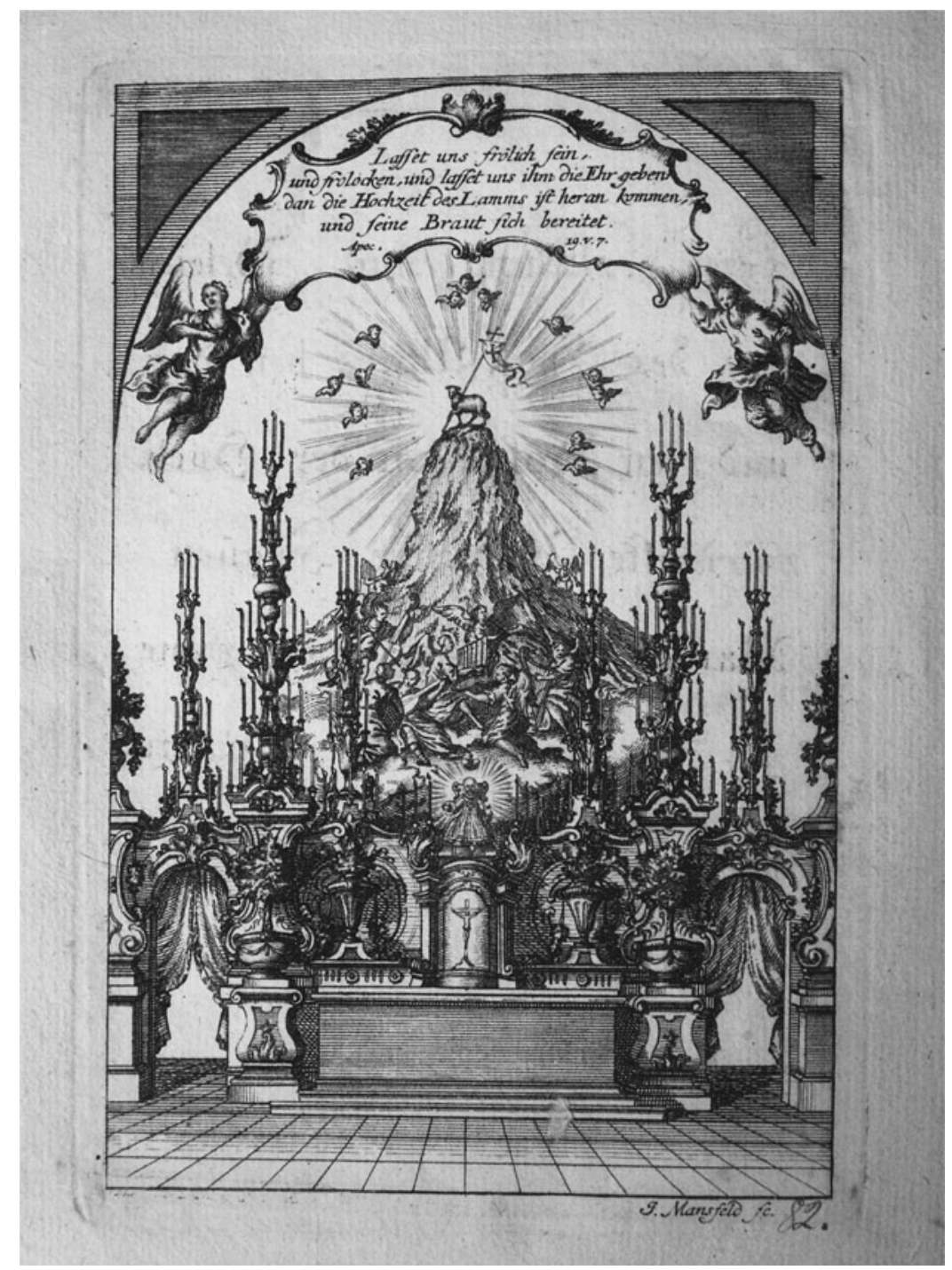

FIgURE 1: Graphic showing the decoration of the altar on the occasion of the golden jubilee of Maria Innocentia countess Nigerelli in 1757 (Photo Veronika Čapská. Archives of the author).

Nigerelli, the superior of the Viennese convent of canonesses regular at Porta coeli in 1757 (see Figure 1). Because the actual printed sermon from the event is also preserved, it is possible to find out that a cartouche in the upper part of the image frames the quotation from Revelation, which also served as the motto of the oration: "Let us rejoice and exult and give Him glory, for the wedding of the Lamb has come and his bride has prepared herself." (Rev. 19: 7). ${ }^{72}$ The

\footnotetext{
72"Lasset uns fröhlich sein und frohlocken, und lasset uns ihm die Ehr geben; dan die Hochzeit des Lammes ist herankommen, und seine Braut (hat) sich bereitet.” Marianus Schörckmayr, Erneuerte Vermählung des Lamms mit der Unschuld, als die ... Frau Maria Innocentia gebohrne Gräfin von Nigrelli, des hochlöblichen, und fürstlichen Stifst deren ... Chorfrauen S. Augustini zu der Himmelpforten in Wien würdigste Frau Oberin, und Pröbstin, nach verflossenen 50 Jahren ihre h. Ordensgelübde... das zweyte mal abgeleget (Vienna, [1757]).
} 


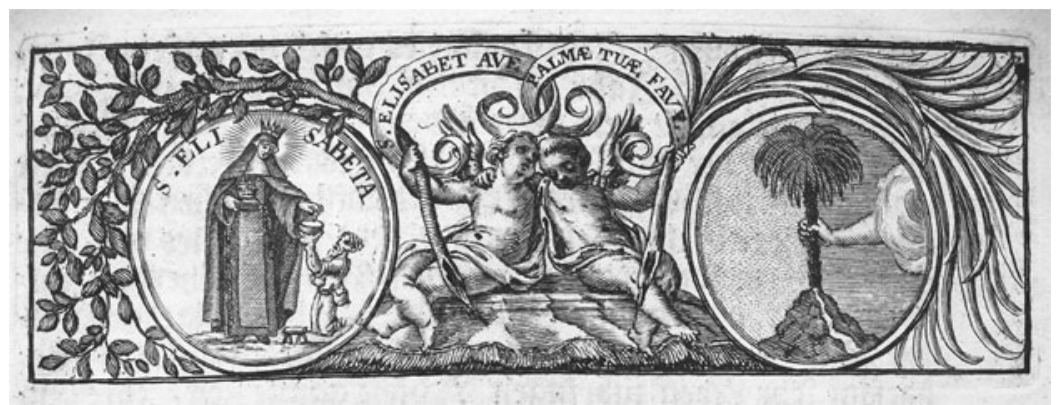

Figure 2: The frieze in the sermon on the occasion of religious vows of Josephine Catherine of Martinsberg in the convent of St. Elisabeth order in 1737 (Photo Veronika Čapská. Research library in Olomouc, shelf mark 994.093/přív. 24).

quotation itself evokes and enforces the atmosphere of celebration. At this point, it is thus suitable to emphasize that printed orations, in combination with preserved images, can give us very valuable insights into the complexity of baroque festivities and the roles played by the visual, the oral, and the auditory in them. The sermons themselves are originally oral performances that took place in the context of visual adjustments of the churches and their surroundings with special decoration, illumination, and accompanying music. The printed orations thus should be seen as an integral part of the concept of the baroque Gesamtkunstwerk, that is a harmonious complex in which the oratory, visual, and musical levels were united.

Besides larger images that could have been preserved separately from the sermons or bound in them, smaller visual motifs were an integral part of the layout of the pages, especially friezes, vignettes, and decorated initials. These in-text illustrations were usually more general in character, representing floral and vegetative ornaments, but occasionally more specific motives were introduced (see Figure 2), as in the sermon on the occasion of the profession of Josepha Catharina of Martinsberg that took place in the Elisabethan convent in Prague in 1737. The frieze shows St. Elisabeth as the patron saint of the Elisabethan order and a palm tree as an allusion to the coat of arms of the Martinsberg family. ${ }^{73}$ In the midst, two putti are holding the inscription pleading St. Elisabeth to show her favor to the young nun-to-be: "Hail St. Elisabeth, be favorable to your palm!"74 The joint usage of the symbols of religious and secular status clearly conveys the importance attached to the family representation when members of nobility were entering a religion.

Whereas in-text illustrations with heraldic motives were relatively rare, single graphic sheets with the family's coats of arms were frequently bound in sermons relating to noble ladies' entries. At times a more original, individually adjusted graphic may have been composed, such as the graphic sheet bound in the sermon on the entry of Maria Elisabetha countess of Salm into the convent of Dominican sisters in the Old Town of Prague on 21 April 1716. It contains a scene of Christ presenting a ring to a young countess of Salm at the center. Above the scene there are allied coats of arms of the Salm family and the Dominican order. The central image of spiritual betrothal is framed in an architectural structure and flanked by the

\footnotetext{
${ }^{73}$ Julius Franciscus Waha, Der Lieblich grünende Palmenbaum in das irdische Paradeis der heil. Elisabeth übersetzet, da Maria Rosalia Godefrida à S. Theresia, vorhero Josepha Catharina von Martinsberg in den Geistlichen Orden der heil. Elisabeth ... die heilige Profession abgelegt ... (Prague, 1737).

74“"S. Elisabet ave, palmae tuae fave!" Waha, Der Lieblich grünende Palmenbaum.
} 


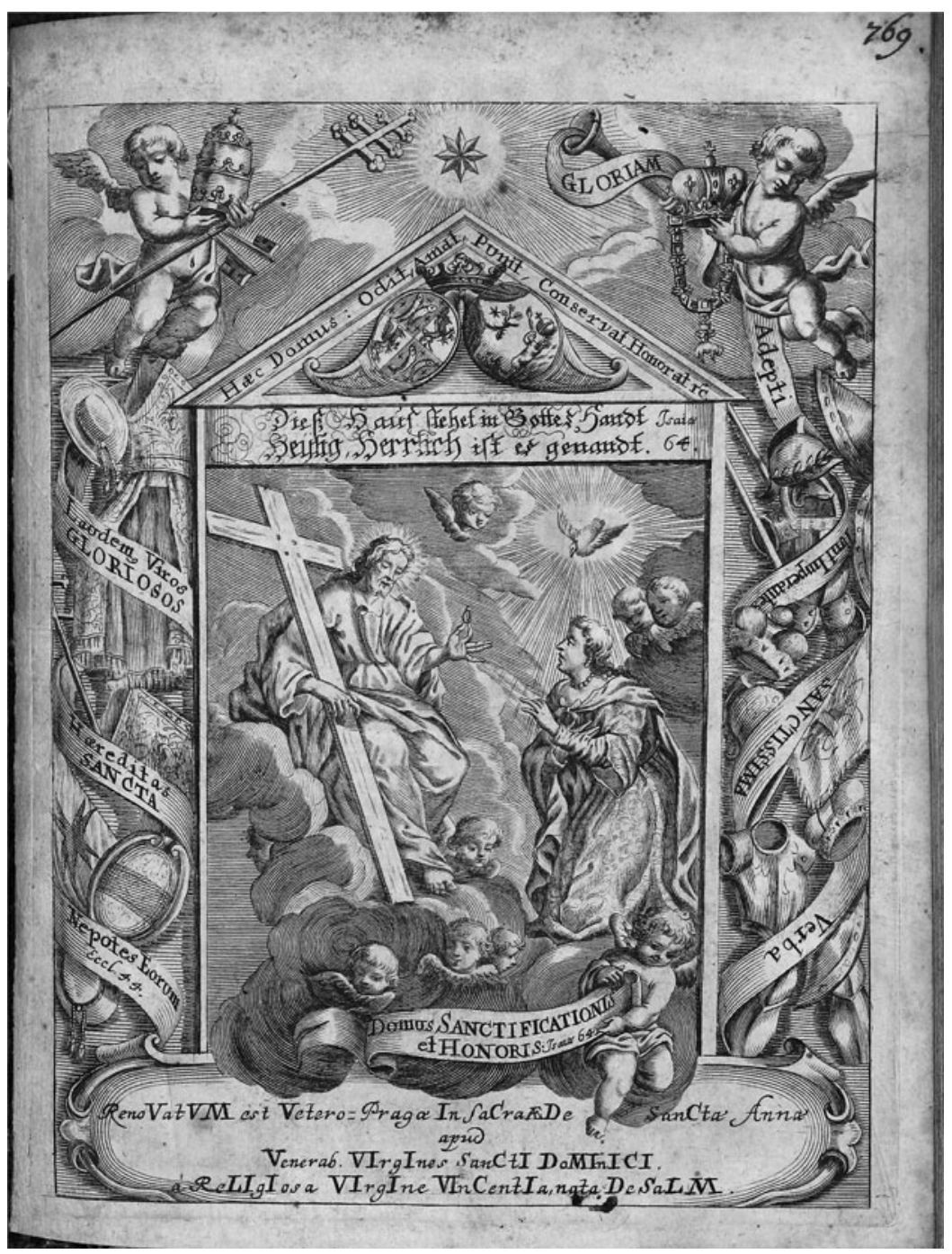

FIGURE 3: The graphic sheet in the sermon on the entry of Maria Elisabetha countess of Salm into the convent of Dominican sisters in the Old Town of Prague in 1716 (Photo Vilém Kaplan. Moravian library in Brno, shelf mark ZK-0000.749, prrív. 33).

attributes of church power on the side of Christ and secular power on the side of the candidate who is bringing these insignia to sacrifice them to her spiritual groom and also to empower the religious institution she is entering (see Figure 3). ${ }^{75}$ The sermon abounds in the figurative language of building a house, probably an allusion to the significant enlargement of the convent that was being carried out at that time by Christoph Dientzenhofer and presumably also as part of the effort to attract attention of the families of potential candidates and

\footnotetext{
${ }^{75}$ Laurentius Carol Brückner, Haus der Heiligung und Herrlichkeit in sittliches Seelengebau eines lebendigen Tempel Gottes erneueret; an der ... Freyle Maria Elisabetha Sidonia Eva Rosalia gebohrnen Gräfin von Salm, mit feyerlich geziemender Geisteseinrichtung gebildet und als selbe ihren gewünschten Standwechsel anzutreten nach herrlicher Einzug durch die königliche Prager Städte ... (Prague, [1716]).
} 
patrons. ${ }^{76}$ On the title page the preacher claims to have rhetorically built the structure of the sermon (rednerisch erbauet). On another level, the young candidate should carefully watch over her own house: "Guards come here! To the main gate of the holy house! Both, you main guards of the soul: reason and will."77 Both text and the image that accompanies the sermon and frames the scene of spiritual betrothal in architectonic structures, invite the viewers and readers/listeners to perceive the event in terms of building a spiritual structurethus communicating a central message loaded with a particular range of meanings and at the same time leaving out other possible interpretations of the event.

As we have seen, important parallels can be drawn between the images, that frame their central messages with the meaning(s) of a particular festivity, and the texts to which they are attached, which attempt to do the same by literary means.

\section{Functions and Uses of the Sermons}

It seems that the public representation and attraction of attention to convent life constituted the main functions of the occasional homiletics connected with the female convents. The sermons represented particular convents, as well as whole religious orders. Besides their function to commemorate the acts of individuals embracing of convent life publicly, they also served the purpose of social networking. We can label them as the "socially oriented genre." This useful term was introduced by Abigail Brundin for the monachization poems that emphasized the alliance-building role of women when entering marriage, or as in our case, a convent. ${ }^{78}$ The $^{2}$ sermons exploited the potential of women to forge or strengthen social ties between their families and religious institutions.

More recently established religious orders seem to have been particularly active in the use of printed sermons: There are especially large numbers of orations preserved for the Ursulines and the Order of St. Elisabeth, the major religious orders that spread the new model of more active (although enclosed) female religious life, and which strove to build new social ties and to break into the network of the female convents of the old orders, such as the Benedictines, the Cistercians, or Poor Clares in Central Europe.

Convents in largely Protestant areas, such as Silesia, especially needed to popularize their mission and gain new vocations. For example, the sermon on the vestition of Theresia Magdalena von Metternich in the Ursuline convent in Wrocław (Breslau) in 1694 drew attention to the lifestyle and teaching activities of the nuns. It also pointed out the successful growth of their community in recent years and expressed hope for more young candidates: "Oh, what a small flock, hardly a handful of Ursulines was in Bresslau at the start several years ago. One could count them on the fingers of one hand: they were exactly five. Now,

\footnotetext{
${ }^{76}$ Petr Sommer and Pavel Vlček, "Bývalý klášter dominikánek s kostelem sv. Vavřince a sv. Anny [Former Convent of Dominican Nuns with the Church of St. Lawrence and St. Anne]," in Encyklopedie českých klášterů [Encyclopedia of Religious Houses in Bohemia], ed. Pavel Vlček, Petr Sommer, and Dušan Foltýn, 506-508 (Prague, 1997), at 507.

77"Wacht her! Zum Haubt-Thor deß heiligen Hauses! Ihr beede Hauptwachten der Seele: Vernunft und Willen." Brückner, Haus der Heiligung.

${ }^{78} \mathrm{Cf}$. "Monachization poetry allows for the use of occasional lyrics to negotiate a space in which women can continue to fulfill their public, alliance-building function, even as their exit from secular society is memorialized and celebrated. Convents, families, and individuals all benefited from this socially-oriented genre, which transformed the convent threshold into a politically charged liminal space for networking and negotiation, a last moment of exposure for a young woman before she embraced a future life in seclusion." Brundin, "On the Convent Threshold," 1133-34.
} 
however, God be praised there are rising up to thirty of them and more young plants are blossoming in near and good future."79 In this case, the Jesuit preacher Christopher Eligner skillfully demonstrated the potential offered by the sermon to serve as an instrument of communication and publicity.

The sermons in the Ursuline churches frequently made use of the engaging topic of the missions of the Ursulines in Quebec. The stories about distant, hardly accessible places must have aroused attention and unleashed the imagination of the listeners. Printed orations related to other female religious orders, however, employed this subject rarely. An interesting exception was provided by a sermon, delivered by the Jesuit Friedrich Kauschke in 1737, on the profession of Theresia Skorzepin in the convent of the nuns of St. Elisabeth in Prague: ${ }^{80}$

Tell me: who was amongst the first who held out Jesus Christ's shepherd's staff dripping with blood, the salutary sign of the cross of the Redeemer, towards the erring black heathen sheep in untamed America? Oh! After the apostles it was also a seraphic shepherd Franciscus in his brothers. Who gave the evangelical seed to the hungry lambs in the so called Fortunatis and Canary or Seven Indian Islands of the West Indies around 1450? Oh! It was St. Didacus, a dear child of St. Francis, together with other religious brothers [...] Yes, in Japan the sons of St. Francis together with three other Jesuits in Nangazachi were among the first [...] who risked their lives and bodies out of love to their sheep [...] Right up to the testimony of martyrs, to bloodshed. Oh love! Oh seraphic love! Oh burning shepherd Francis! Holy martyrs, magnanimous blood witnesses of the sole sanctifying Christ's stable of the Roman Catholic Church amount already to 1500 in the yearly registers. No fire, no sword, no death, no cruelty can keep the children who imitate the seraphic shepherd of souls from seeking the lost, curing the sick, protecting the endangered and saving the dying. ${ }^{81}$

With references to the overseas missions, the preachers strengthened the feeling that as members of religious orders, individuals could spiritually participate and engage in the

\footnotetext{
79“'O wie ein kleiner Hauffen, kaum eine Handvoll Ursuliner waren vor etlichen Jahren Anfangs in Breßlau: man kunte sie an Fingern zehlen; Es waren ihrer gantzer Fünffe: Jetzt aber Gott sey Lob steigen sie schon bis auf dreysig und blühen noch mehr junge Pflantzel in nächster und guter Hoffnung." Christophorus Eligner, Bißhero auf Erden, Hinführo im Himmel; Das ist Glükseelige Nahmens- und Standsveränderung der Hoch- und Edel- Wohlgebohrnen Theresiae Magdalenae Fräule Gräfin von Metternich als sie in ihrem Eingang in die Gesellschaft S. Ursulae in Bresslau zu Maria Hülf sich Maria Felicitas nennete... (Bresslau, [1694]).

${ }^{80}$ In the convent of the nuns of St. Elisabeth, Theresia Skorzepin accepted the name Maria Ludovica of the five wounds of St. Francis, and her profession was celebrated on the feast of St. Francis. This circumstance thus created a suitable occasion to refer to the missionary followers of St. Francis while preaching on behalf of a new nun. Cf. Friedrich Kauschke, Der Seraphische Seelenhirt Franciscus von Assis, Stifter und Patriarch des jungfraulichen Elisabethiner-ordens unter der dritten Regel mit seinem seraphischen Schäfflein ... Jungfrau Maria Ludovica von fünf Wundmahlen des heiligen Vaters Francisci... (Prague, [1737]).

81 "Dann sage einer: wer hat unter den Ersten im zaumlosen America den bluttriefenden Hirtenstab Christi Jesu das Heilbringende Creuzzeichen des Erlösers irrigen schwarzen heidnischen Schäflein ausgestecket? Ach! Es ware nach den Aposteln auch ein seraphischer Seelenhirt Franciscus in seinen Ordenskindern. Wer hat um das Jahr 1450 in den so genannten Fortunatis, und Canarischen oder sieben Indianischen Eiländern des gegen Sonnenuntergang gelegenen Indien unter den ersten den evangelischen Saamen hungrigen Lämmlein vorgeworfen? Ach! Es ware ein heiliger Didacus, ein liebes Kind Francisci mit andern Ordensgenosen...Ja in Japonien waren die Söhn Francisci unter den Erstlingen [...] welche aus Liebe ihrer Schäflein mit dreien andern aus der mindesten Gesellschaft Jesu zu Nangazachi, Leib und Leben in die Schanz geschlagen...Bis zur Zeugnis der Marter, bis zur Blutvergießung. O Liebe! O seraphische Liebe! O brennender Hirt Francisce! Schon 1500 heilige Martyrer, großmüthige Blutzeigen des allein seligmachenden Schaafstalls Christi der Römisch Catholischen Kirchen zehlet aus deinen Kindern in den Jahrsregistern ... Kein Feuer, kein Schwerdt, kein Tod, keine Grausamkeit kan die nachahmende Kinder des Seraphischen Seelenhirten abschröcken dass sie nicht suchen, was verlohren, heilen, was kranck, hüten, was gefährlich, retten was untergehet." Kauschke, Der Seraphische Seelenhirt.
} 
missionary effort of their religious institutions. This is significant given the fact that Central European nuns could not personally participate in the overseas missions, unlike members of some male orders in the Habsburg monarchy, especially Jesuits and Franciscans, who applied in great numbers for the permission to be sent overseas. Some were entrusted with this prestigious task. ${ }^{82}$ The sermons thus served as means of nourishing the collective representations of a renewed and expanding Catholicism and at the same time as a means of imparting to the nuns that their privileged space of operation was the landscape of their souls, where they could fight the vices, support the church militant, and even act as imaginary missionaries by means of their prayers and ascetic practices.

Two sermons preserved for Maria Elisabeth from the Silesian lower noble family Kalkreuth of Dolzig illustrate this particular aspect. At the time she entered a convent, her brother was building a late baroque chateau. This coincidence fuels the suspicion that her entry into a convent might have smoothed the way for a family of limited means to build a new residence according to the latest standards. The Jesuit preacher Martin Raab, one of those who specialized in the genre of sermons on the entry into a convent, chose for the sermon on the occasion of Maria Elisabeth's veiling a motto that probably surprised the audience (surprise being a desirable effect in emblematic sermons) - a motto taken from the gospel of Mathew: "Go and teach all nations, baptizing them in the name of the Father, the Son and the Holy Spirit and behold I am with you to the world's end" (Mt. 28: 19-20). ${ }^{83}$ In accordance with the convention of the genre, the preacher also used the name of the honored person as a figure and the starting point for the whole sermon as he elaborated on her newly acquired religious name-Maria Angela of the Heart of Jesus. He used her new predicate, "of the Heart of Jesus," to emphasize that although she was not sent to teach all nations, she was called to go into her heart, to preach Christ to herself. There, inside her heart, she would find so many inner dispositions as there are "wild nations" and so many passions as there are tyrants in the world. ${ }^{84}$

The occasional sermons connected with female convents served the public representation of both the institutions and the families related to the individual nuns. While the convents or their patrons usually commissioned the sermons on institutional anniversaries, golden jubilees, and installations of nun superiors, families were more active in financing the sermons when family members entered a religious community. For the families, the printed sermons offered a welcome opportunity to burnish the family reputation for "pietas" and to draw attention to significant ancestors, the family coat of arms, and stories about the family's origin.

In the above-mentioned sermon on the occasion of the veiling of Maria Elisabeth of Kalkreuth and Dolzig in 1744, for example, the preacher used the motifs of eagle and laurel and the heraldic figure of a blackamoor from the family coat of arms. He mentioned the ancestor Wolfgang of Kalkreuth, who had participated in the defense of Vienna during the

\footnotetext{
${ }^{82}$ Early modern Central European missionaries who were sent overseas have attracted the attention of scholars for a long time. Cf., for example, Zdeněk Kalista, Cesty ve znamení křiže. Dopisy a zprávy českých misionářù 17. a 18. věku ze zámořských krajü [Travels in the Sign of the Cross. Letters and Reports of Czech Missionaries of the Seventeenth and Eighteenth Centuries from Overseas] (Prague, 1947).

83"Gehet hin und lehret alle Völcker und tauffet sie im Nahmen des Vatters und des Sohns und des heiligen Geistes-und sihe ich bin bey euch biß ans Ende der Welt.” Martin Raab, Das Hertz Jesu, in allerhöchster Beywohnung deren drey-einigen Göttlichen Persohnen erziehlet von der wohlgebohrnen Fräulen Fräulen Maria Elisabeth Freyin von Kalckreuth und Doltzig; als selbte unter dem Nahmen Maria Angela von dem Hertzen Jesu durch feyerlichen ... Eintritt in die Gesellschaft der heiligen Ursula von der Welt abweichet sich Christo zu verähnlichen... (Olomouc, [1744]).

${ }^{84}$ Raab, Das Hertz Jesu.
} 
Ottoman siege in 1529, and he emphasized that another ancestor, Karl Friedrich of Kalkreuth, had been raised to the state of baron (Freiherr) by emperor Leopold I in $1678 .{ }^{85}$

In a different sermon on the occasion of the veiling of another young lady, Barbora Elisabeth Sedlnická of Choltice, in the convent of the Dominican sisters in Olomouc in 1713, the Premonstratensian Gottfried Fragstein emphasized the reputed kinship of the candidate to the medieval Dominican Saint Hyacinth and made use of the genealogical fiction that the Sedlnický family and St. Hyacinth shared a coat of arms. ${ }^{86}$ In this way, the preacher demonstrated the alliances under construction and rhetorically reinforced them.

When introducing the families of the young nuns-to-be, the preachers relied on celebratory genealogical works to spread stories about their glorious past. For example, the Jesuit Joseph Piczon referred to several genealogical works in his vestition sermon for future Ursuline, Anna Maria Příchovská of Př́chov, as he claimed that her noble forefather Rohovec had already lived in Bohemia when the mythological Slavic brothers Čech and Lech arrived to settle in Bohemia and Poland, respectively: "It is well-known that your noble house is counted among the oldest families in the kingdom of Bohemia; it can be held as trustworthy that it already marvellously flourished under the noble name Rohovec in the above mentioned kingdom approximately around 300 after Christ, in the times of the princely brothers Czech and Lech. And it continued to thrive happily and grow to the present day." ${ }^{\prime 7}$ Such genealogical fictions were an integral part of the self-representation of noble families, virtually exploited on every occasion and in every printed text related to the family-even in the convent entry sermons. This is well illustrated by the vestition and profession sermons delivered for Maria Anna, countess of Sternberg, by Johann Steiner. Steiner skillfully worked with the fictitious family tradition that celebrated the family's chief heraldic figure, a golden star, and derived the family's origin from one of the three Magi from the East, who were lead by the star to worship baby Jesus. ${ }^{88}$ In the profession sermon, Steiner writes: "Highly noble House of the Imperial Count of Sternberg! You unite your ancient noble origin with your name and the name with your coat of arms. The coat of arms shows the noble star in the blue field. Where did this star take its initial light from, if not from the miraculous star which moved above the heads of the kings of the orient preceding them to the birthplace of the King of all kings?" ${ }^{99}$ Passages like this confirmed and promoted the social exceptionality of family and convent alike.

\footnotetext{
${ }^{85}$ Ibid.

${ }^{86}$ Gottfried Fragstein, Beliebige Veränderung der hochgebohrnen Freyle Freyle Barbara Elisabeth Freyin Sedlnitzkin von Choltitz als sie bey herrlichen Braut-Eingang und hochzeitlichen Freudentag der erwünschter Einkleidung in dem berühmten Jungfrauen-Closter bey St. Catharinam, dess hochlöblichen Ordens S. Dominici... (Olomouc, [1713]). See also Bartoloměj Paprocký, Zrcadlo slavného Markrabství Moravského [Mirror of the Famous Moravian Margraviate] (Olomouc, 1593).

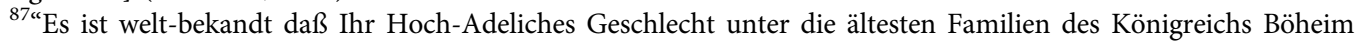
müsse gerechnet werden; ja für glaubenswürdig zu halten kommt daß solches schon bei nahend umb das Jahr Christi $300 \mathrm{zu}$ denen Zeiten deren fürstlichen Gebrüdern Czechi, und Lechi, unter dem Edlen Nahmen Rohowecz in obgemeldtem Königreich wunderschön geblühet habe und biß heutiges Tages in seinem immerwehrenden Flor und Wachßthumb glücklich bestanden seye...." Josephus Piczonn, Glorreicher Tauben-Schwung aus dem gefährlichen Weltmeer in die geistlichen Archen der hochlöblichen Gesellschaft S. Ursulae, von einer wohlgebohrnen Fräule Anna Maria Josepha Freyin Rohoweczin Przichowskyn von Przichowicz trostreich angestellet... (Prague, [1726]).

${ }^{88}$ Steiner, Der in den Himmel übersetzte Stern; Steiner, Die Sonn unter der Wolcken.

89 "Hochadeliches reichsgräfliches Haus von Sternberg! Dein uraltes hohes Herkommen vereinigest du mit dem Namen und den Namen vereinigest du mit dem Wappen; das Wappen führet den hochadelichen Stammenstern in dem blauen Feld; woher hat dieser Stern sein erstes Licht ererbet als von jenem Wunderstern welcher ob denen
} 
The public representation of both the religious institutions and the families could be significantly intensified when members of the Habsburg court participated at the festivity. The visits of the members of the Habsburg family and prominent courtiers are always emphasized on the title pages of the sermons. A good example is the case of the festive reception of the habit by Josepha of Rebenstein in the convent of the Viennese Ursulines in July 1743, when the Archduchess Maria Anna of Austria, the younger sister of the queen and soon-to-be empress Maria Theresa, participated at the event accompanied by the court of her widowed mother Elisabeth Christine of Brunswick-Wolfenbüttel. ${ }^{90}$ Probably in honor of the special imperial guest, the novice was given the name Elisabetha Christina.

Occasionally convents elsewhere also took pride in a court visit, as, for example, in the case of the festive entry of Elisabeth Catharina of Harrach into the convent of the Ursulines in Prague when the imperial pair Leopold I and Eleonore Magdalene of Pfalz-Neuburg added glamour to the event. ${ }^{91}$ The Viennese convents of course had far more opportunities to enjoy the honor of a court visit, as we see from the passage in the jubilee sermon on behalf of Maria Innocentia countess Nigerelli: "the first betrothal of Innocentia with her celestial groom was blessed by the late Roman Emperor and Empress Joseph the First with Amalia and Eleonora [queen mother-V. C..] and the second was confirmed with the highest consent of Her Royal Highness Maria Theresia herself." 92

The above examples show that printed sermons commemorating the initiation into convent life offered the families of young women a welcome opportunity to display the family pietas as it complied with the official pietas austriaca and to publicize a change in the social status of a family member. ${ }^{93}$ The transition from one social status to another is often explicitly mentioned in the titles of sermons with terms like "Standwechsel" or "Standsveränderung" in German. The Czech sermon on the occasion of Maria Lidmila Antonia of Ríčany receiving the habit of the Poor Clares convent in the Old Town of Prague in 1720 emphasized her change in social status by using the phrase "stav svůj světský změníc v stav duchovní," that is "changing her secular status to religious status." 94 The convents, too, seem to have been interested in attracting attention to the public acts of choosing convent life.

Häuptern deren Morgenländischen Königen zu dem Geburtsort des Königs aller Königen ist vorangegangen?” Steiner, Die Sonn unter der Wolcken.

${ }^{90}$ Karl Tusseng, Lehrstück, da in hoher Gegenwart der Durchläuchtigsten Ertzherzogin Mariae Annae ... Die feyerliche Einkleidung der hoch- und edelgebohrnen Fräule Josephae von Rebenstein ... (Vienna, 1743).

${ }^{91}$ Caspar Knittel, Bisshero Harrachin, nunmehro Seraphin. Das ist Seraphische Bekehrung der ... Elisabeth Catharina ... Fräule Harrachin ... In Ihrem eingang in die Gesellschaft S. Ursulae ... (Prague, 1679).

92“die erste Vermählung Innocentiae mit ihrem himmlischen Bräutigam, haben als die höchste Zeugen Joseph der Erste mit Amalia und Eleonora Römische Kaiser und Kaiserin seligster Gedächtnuß begnadet, und die zweite bestättiget mit höchster Genehmhaltung die höchste Hoheit selbst Maria Theresia." Schörckmayr, Erneuerte Vermählung.

${ }^{93}$ On "pietas austriaca," cf. Anna Coreth, Pietas Austriaca. Österreischische Frömmigkeit im Barock (Vienna/ Munich, 1982). More recently, an attempt to decentralize the concept has been made by Marie-Elizabeth Ducreux, "Emperors, Kingdoms, Territories: Multiple Versions of the Pietas Austriaca?" Catholic Historical Review 97, no. 2 (2011): 276-304.

${ }^{94}$ Michael Pelischotti, Lidumila, aby byla Bohumila. Totiž vysoce urozená slečna Marya Lidmila Antonya z Říčan. Stav svi̊j světský změníc v stav duchovní v chrámně Páně S. Panny Anyžšky Mučedlnice př̀i klášteře panenským S. Panny Matky Kláry v Starém Městě pražském v den oblačení svého 17. měsíce června kázáním sprostým vyobrazena [Lidumila that would be dear to God. That is highly noble lady Marya Lidmila Antonya of Řićany. Changing her secular status to religious status in the Church of Saint Virgin Martyr Agnes in the convent of Virgins of Saint Mother Clare in the Old Town of Prague on June 17, the day of her veiling, depicted in a simple sermon] (Prague, 1720). For the reference to this and other sermons, I am grateful to Hedvika Kuchařová. 
The young candidates' change of status was usually rendered as a death to the world. For example, the Franciscan Benno Hupp presented the three young women who were entering the convent of Poor Clares in Graz in Styria in 1687 as singing a song of dying swans. ${ }^{95}$ The friar minor Gabriel Poltzer expressed his best wishes to the newly professed Poor Clares in terms of peaceful death to the world: "Grant them eternal rest, O Lord; and may perpetual light shine upon them." 96 The Jesuit preacher David Freisleben was rather explicit in describing the vestition of Barbara Rosina von Millenau in the Ursuline convent in the Silesin town of Schweidnitz (Świdnica) in 1730 by the following words: "Now we are burying you in your life and alive you are going into your own grave." ${ }^{97}$

To a certain extent, the monachization sermons thus fulfilled the function of funeral sermons. It is therefore difficult to find evidence for the phenomenon of funeral sermons for deceased nuns in the Habsburg monarchy. At the same time, however, there was a strong tradition of printed funeral sermons for Catholic bishops. ${ }^{98}$ However, if we search for funeral sermons for female regulars, it becomes clear that they were published very rarely. Such examples are hard to trace and, as I shall show in the following lines, they are exceptional. The National Library in Vienna houses two funeral sermons commemorating the deceased abbesses of the Benedictine convent at Nonnberg in Salzburg, which enjoyed a somewhat special status as the oldest female religious house in the German-speaking area and Central Europe in general. ${ }^{99}$ Moreover, the Archbishopric of Salzburg was not an integral part of the Habsburg monarchy in the early modern period, but an independent prince-bishopric and state of the Holy Roman Empire.

Another rare example of a funeral sermon for an abbess is preserved in the National Library in Prague and concerns the deceased abbess of the Benedictine convent of St. George at the Prague castle, Maria Josepha von Fürstenberg. Her case is also exceptional, because Maria Josepha was born a princess of the Holy Roman Empire (des heiligen Römischen Reichs Gebohrne Fürstinn) and in addition to the office of superior of this oldest convent in the Bohemian lands, she bore the honorary title of princess-abbess. ${ }^{100} \mathrm{We}$ can thus see that the rare practice of funeral sermons for abbesses was for a long time limited to convents with very high social status.

\footnotetext{
${ }^{95}$ Hupp, Schwannen Flug und Flucht.

96“Requiem aeternam dona eis Domine, at lux perpetua luceat eis." Poltzer, Drey verliebter.

97"Jetzt begraben wir dich in deinem Leben und du gehest bey lebendigen Leib in dein selbst eigenes Grab." David Freisleben, Gnadenreicher Beruff des gutten Hirtens; getreue Nachfolg des gehorsamben Schäfleins auf der Unschuldigen Weyde des Geistlichen Ordenstandes, als die ... Fräule Barbara Rosina Freyin von Millenau das heilige Ordenskleid der Gesellschaft der heiligen Ursulae ... an sich genommen (Schweidnitz [1730]).

${ }^{98}$ Radmila Pavlíčková, Triumphus in mortem. Pohřební kázání nad biskupy v raném novověku [Triumphus in mortem. Funeral Sermons Over Early Modern Bishops] (České Budějovice, 2008).

${ }^{99}$ Alanus Pfeiffer, Thesauri nivis. Die bißhero verdeckte, nunmehro aber entdeckte Schätz des Schnees. Das ist: Auferbäulicher Tugend-Wandel Weyland der Hochwürdigen in Gott wohlgebohrnen ... Frauen Mariae Magdalenae von Schneeweiß und Weissenberg deß uralten Stüffts ... Nunberg zu Saltzburg Würdigster Abbtissin: Bey hochansehlich-gehaltener Erd-Bestättigung auf der Trauer-Cantzel einem vornehmen, und Volck-reichen auditorio vorgetragen (Salzburg 1715); Simpert Schwarzhueber, Trauerrede auf die ... Frau Maria Scholastika Augustina, gebohrne Gräfin von Wicka etc. etc. des ... Benediktiner-Frauenstiftes am Nonnberg zu Salzburg ... bey Hochderselben Beerdigung in der Stiftskirche allda den 27 Brachmonaten 1783 gehalten (Salzburg, [1783]).

${ }^{100}$ Johann Nepomuck John, Trauer und Lobrede auf die Hochwürdigst-Durchlaüchtigste Frau Frau Marien Josephen, des heiligen Römischen Reichs Gebohrne Fürstinn zu Fürstenberg, Von Gottes Gnaden Fürstinn und Abtißinn des Uralten Königl. Jungfräul. Kloster-Stifts bey St. Georg ob dem Königl. Prager Schloß ... als Hoch Deroselben feyerlichen Leichbegängniß den 12. Tag des Monats Hornung 1770 (Prague, 1770).
} 
We may hypothesize that in the course of the eighteenth century, there might have been a tendency to further differentiation within the genre of sermons related to individual nuns that had for a long time merged the features of nuptial and funeral sermons. This can be illustrated by two Hungarian examples of funeral sermons that come from the later part of the eighteenth century and are connected with the deaths of two very young nuns. One of them was probably published at the initiative of the convent of Ursulines in Raab, and the other was clearly initiated by the father of the deceased young woman "as a sign of the dearly tender love towards his daughter" (zum Zeichen der inniglich zarten Liebe gegen seiner Tochter) and published in Sopron. ${ }^{101}$

Nonetheless, funeral sermons for female religious figures remained a rare phenomenon and it seems that there was a strong preference for attracting public attention to the renewal of religious institutions rather than to the public commemoration of the dead.

\section{Conclusion}

The aim of this article has been to show that the monachization sermons can provide us with new perspectives on early modern convent cultures. These sources should not be neglected, as they give us valuable insights into a broad range of aspects of early modern convent life and of its perception by outsiders. Moreover, because one of the main functions of the monachization sermons was the public representation of both the religious institutions and families of the young nuns-to-be, they offer a valuable opportunity to merge creatively the study of the social and devotional practices pertaining to both sides of the convent wall.

Although initiation rituals connected with the entry into convent life were regulated precisely by both canon law and the rules of the respective religious institutions, we can conclude that the preachers' orations played an important role in explaining the ritual to a wider audience and in representing and imagining the ideal of a female religious life. The sermons allowed for a selective foregrounding of some aspects of the process of monachization and convent life and tied together the various punctuated elements of the scene. As a genre, the sermons created the authoritative frame within which further utterances about early modern nuns were formed. The printed sermons can thus be regarded as part of the celebratory discourse on early modern nuns.

I have focused mainly on the ritual, textual, and communicative levels that merge in my conclusion remarks. But there are more aspects to be explored. It should be emphasized that over the long term the monachization sermons' stunning rise in popularity coincided not only with the revitalization of female convents in the Habsburg monarchy, but also with the increase in pressure for the enclosure of nuns and with the growing accessibility and affordability of printing press technology. The interconnectedness of these phenomena

\footnotetext{
${ }^{101}$ Cf. both anonymous works: Jesus, Maria, Ursula. Im Jahr ... 1749, den 23sten May ... ist in unserem Closter der Gesellschaft S. Ursulae, allhier in Raab, seelig im Herrn entschlaffen unsere ... Mit- und Chorschwester, Maria Anna Catharina Xaveria von der Geburt Jesu vorhero Fräule Jászin von Kutnár ... ihres alters 29sten ... Jahr ([Raab, 1749]); Höchst schmerzliche Trauer-Klage, welche über den frühzeitigen Hintritt Michaeli Prantnerin weyland gewesten Kloster-Jungfrauen, so den 26. Juni 1765 aber in dem 19. Jahr ihres Alters das zeitliche Leben geendet, wehmüthigst führte und zum Zeichen der inniglich zarten Liebe gegen seiner Tochter selbst verfassete der Seeligen höchst bestürzte Vater (Sopron, [1765]). Both printed texts are registered in the catalogue of the National Széchényi Library in Budapest, but the collections are still being processed, and I have therefore not been able to access these sermons.
} 
should be explored more thoroughly. In the flourishing genre of monachization sermons, the convents found valuable instruments to reach out and to join their institutional needs for visibility with the candidates' families interests in representation.

In the future, this area of study would also profit from systematic, cross-cultural, and comparative approaches. Interdisciplinary collaboration is vital in this field because historical research into sermons closely overlaps with the fields of literary studies and art history. The literary production that framed the processes of monachization in various parts of Europe seems to have been far larger than scholars might have expected. Moreover, it turns out that the sermons on convent entries and jubilees share many features not only with the orations for newly ordained priests' first masses (primitiae) and their golden jubilees, but also with wedding and funeral sermons. It would therefore be useful to explore exactly how they interconnect nuptial and funeral imagery or how they relate to the other types of sermons.

From an art-historical point of view, it is noteworthy that preachers often referred to permanent and ephemeral decoration related to the festivity, to the convent's past development, its present state, and to possible plans for the future. This enables us also to analyze how convents and their patrons shaped their visual presence in public space. Besides the textual and visual levels, the performative dimension of sermons should also always be kept in mind as it allows the researchers to analyze them as oral events that formed an important part of the early modern festivities culture.

\section{Explanatory note}

Translating early modern texts into contemporary English can lead to significant changes in meaning. For this reason, I have reproduced the original quotations in the footnotes. This approach enables one to preserve such specifics as noble titles and salutations that do not necessarily have English equivalents, and to retain more linguistic aspects of early modern preaching practice, including the usage of Latin mottos that were followed by their translation into the vernacular.

Veronika ČAPSKÁ received her Ph.D. in anthropology from the Charles University in Prague in 2009 and is currently assistant professor in early modern history at the Silesian University in Opava, Czech Republic. She has published extensively on early modern religious orders, gender history, and book culture, recently co-edited the German diarial family records written by a Silesian noble lady Gabriela Sobková of Kornice, married to baron Emmanuel Spens-Booden (1773-1808), and co-edited the volume Between Revival and Uncertainty. Monastic and Secular Female Communities in Central Europe in the Long Eighteenth Century/Zwischen Aufbruch und Ungewissheit. Klösterliche und weltliche Frauengemeinschaften in Zentraleuropa im "langen" 18. Jahrhundert. 